\title{
ASSESSMENT OF THE EFFECTS OF CLIMATE AND LAND COVER CHANGES ON RIVER DISCHARGE AND SEDIMENT YIELD, AND AN ADAPTIVE SPATIAL PLANNING IN THE JAKARTA REGION
}

Poerbandono $^{1}$, Miga M. Julian ${ }^{2}$, and Philip J. Ward ${ }^{3}$

\section{ABSTRACT}

In Jakarta, climate change has been detected through rising air temperatures, increased intensity of rainfall in the wet season, and sea level rise. The coupling of such changes with local anthropogenic driven modifications in the environmental setting could contribute to an increased probability of flooding, due to increases in both extreme river discharge and sedimentation (as a result of erosion in the watersheds above Jakarta and as indicated by sediment yield in the downstream area). In order to respond to the observed and projected changes in river discharge and sediment yield, and their secondary impacts, adaptation strategies are required. A possible adaptation strategy is through policy making in the field of spatial planning. For example, in Indonesia, presidential regulation number 54 year 2008 (Peraturan Presiden Nomor 54 Tahun 2008 - Perpres 54/2008) was issued as a reference for the implementation of water and soil conservation. This paper assesses the impact of climate and land cover change on river discharge and sediment yield, as well as the effects of Perpres 54/2008 on that river discharge and sediment yield. The spatial water balance model STREAM (Spatial Tools for River Basins and Environmental and Analysis of Management Option) was used for the runoff computations, whilst the SDAS model (Spatial Decision Assistance of Watershed Sedimentation) was used to simulate erosion, Sediment Delivery Ratio, and sediment yield. The computation period is from January 1901 to December 2005, at the scale of the following watersheds: Ciujung, Cisadane, Ciliwung, and Citarum. During the $20^{\text {th }}$ century, computed average discharge in the downstream area (near Jakarta) increased between $2.5 \mathrm{~m}^{3} \mathrm{~s}^{-1} /$ month and $35 \mathrm{~m}^{3} \mathrm{~s}^{-1} /$ month, and sediment yield increased between $1 \times 10^{3}$ tons/year and $42 \times 10^{3}$ tons/year. These changes were caused by changes in both land cover and climate, with the former playing a stronger role. Based on a computation under a theoretical full implementation of the spatial plan proposed by Perpres 54/2008, river discharge would decrease by up to $5 \%$ in the Ciliwung watershed, and $26 \%$ in the Cisadane watershed. The implementation of Perpres 54/2008 could also decrease the sediment yield, by up to $61 \%$ and $22 \%$ in the Ciliwung and Cisadane watersheds respectively. These findings show that the implementation of the spatial plan of Perpres 54/2008 could significantly improve watershed response to runoff and erosion. This study may serve as a tool for assessing the reduction of climate change impacts and evaluating the role of spatial planning for adaptation strategies.

Keywords: river discharge, sediment yield, Jakarta, climate change, spatial planning

\section{INTRODUCTION}

Jakarta, the capital city of Indonesia, is extremely susceptible to flooding (Ward et al. 2013), and has a long history of floods due to its naturally flood-prone location (Caljouw et al. 2005, Steinberg 2007). However, flood disaster impacts appear to have become more severe over the last few decades. For example, the city suffered major floods in both 2002 and 2007, the latter causing at least 58 deaths (Texier 2008) and direct economic damages of US\$453 million (Steinberg 2007).

Several factors, both physical and socioeconomic, may be contributing to the apparent increase in flood impacts. Jakarta is naturally flood-prone, being located in a delta of 13 rivers, and experiencing extreme seasonal rainfall intensity (San et al. 2012). On top of this, Jakarta is currently facing rapid land subsidence, especially in the northern (coastal) part of the city, with large parts of the city experiencing land subsidence of $4 \mathrm{~cm} /$ year (Abidin et al. 2010). At the same time, climate change has been signalled by an increase in air temperatures of $1.2^{\circ} \mathrm{C}$ in the 20th century, sea level rise at a rate of $2 \mathrm{~mm} /$ year, and a higher intensity of rainfall in the wet season (Poerbandono et al. 2009, Kartikasari 2009, Julian et al. 2011). But socioeconomic changes are also driving increased flood impacts (Ward et al. 2011a). The city is growing rapidly: over the last half century its population rose from 2.7 
million (1960) to 9 million (2007) (BPS Jakarta 2007). This has also resulted in rapid land cover change, consecutively from forest to agricultural lands, to urban residential and industrial areas (Amien et al. 1996, Verburg et al. 1999; Firman 2009). Open green space within the city has decreased from $28.8 \%$ in 1984 to $6.2 \%$ in 2007 (Firman 2009). These land cover conversions lead to waterproofing of the soil, which in turn leads to a decrease in the infiltration rate (Scalenghe \& Marsan 2009). At the same time, these land cover changes lead to increased erosion rates in the upper and middle watersheds. This causes sedimentation in the river networks in downstream areas (e.g. Jakarta), and reduces the drainage capacity of the city's waterways.

In order to respond to these problems, adaptation measures are needed. In 2008, a presidential regulation number 54 year 2008 (Peraturan Presiden Nomor 54 Tahun 2008 - Perpres 54/2008) was issued, which describes land cover planning in the Jabodetabek region (a region containing the cities of Jakarta, Bogor, Depok, Tangerang, and Bekasi, and covering approximately $6,400 \mathrm{~km}^{2}$ ). Perpres $54 / 2008$ is a reference for the implementation of development related to water and soil conservation; the availability of ground water and surface water; flood prevention; and economic development for the welfare of the community. Perpres 54/2008 is intended to compensate for anthropogenic pressures caused by changes in land cover. Ideally, the implementation of Perpres 54/2008 would lead to increased soil water infiltration capacity, the reduced erodibility of soils, and reduced river flood peaks. This presidential regulation is seen as a possible adaptation strategy through policy making in the field of spatial planning.

In this paper, we aim to improve the understanding of how changes in climate and land cover affect river discharge and sediment yield in the watersheds draining through Jakarta, and to develop a method for estimating the effectiveness of a policy measure regarding land cover regulation for adaptive watershed management. To achieve this, we develop spatial tools, and apply these to address the following research questions:

(1) What are the historical trends in the river discharge and sediment yield of West Java?

(2) What is the relative influence of changes in climate and land cover on river discharge and sediment yield?

(3) How can we apply the tools to assess the effects of Perpres 54/2008 on river discharge and sediment yield?

\section{MATERIALS AND METHOD}

\subsection{Study area}

The study area is situated in the northwestern part of Java, Indonesia, and focuses on major watersheds flowing into the Jakarta Bay (Figure 1). The extent of the land cover plan covered by Perpres 54/2008 is also shown in Figure 1 (see bold line). It covers an area including Jakarta, Bogor, Depok, Tangerang, Bekasi (Jabodetabek), and Cianjur (including Puncak). We computed river discharge and sediment yield for the Ciujung, Cisadane, Ciliwung, and Citarum watersheds. The Jakarta area, including Depok, is situated in the downstream part of the Cisadane and Ciliwung watersheds, while the upstream parts are under the administrative authorities of Bogor and Cianjur. The Ciujung watershed is situated partly in Tangerang, and part of Bekasi is located in the Citarum watershed. The characteristics of the watersheds are given in Table 1. Citarum is the largest watershed studied here, with a size of $8,058 \mathrm{~km}^{2}$; the dominant land cover in this watershed as a whole is agriculture. The Cisadane and Ciujung watersheds have similar percentage covers of agricultural area, namely just over half of the total land area. The Ciujing watershed has the largest proportion of forest cover, whilst the Ciliwung watershed has the largest proportion of built-up area. 


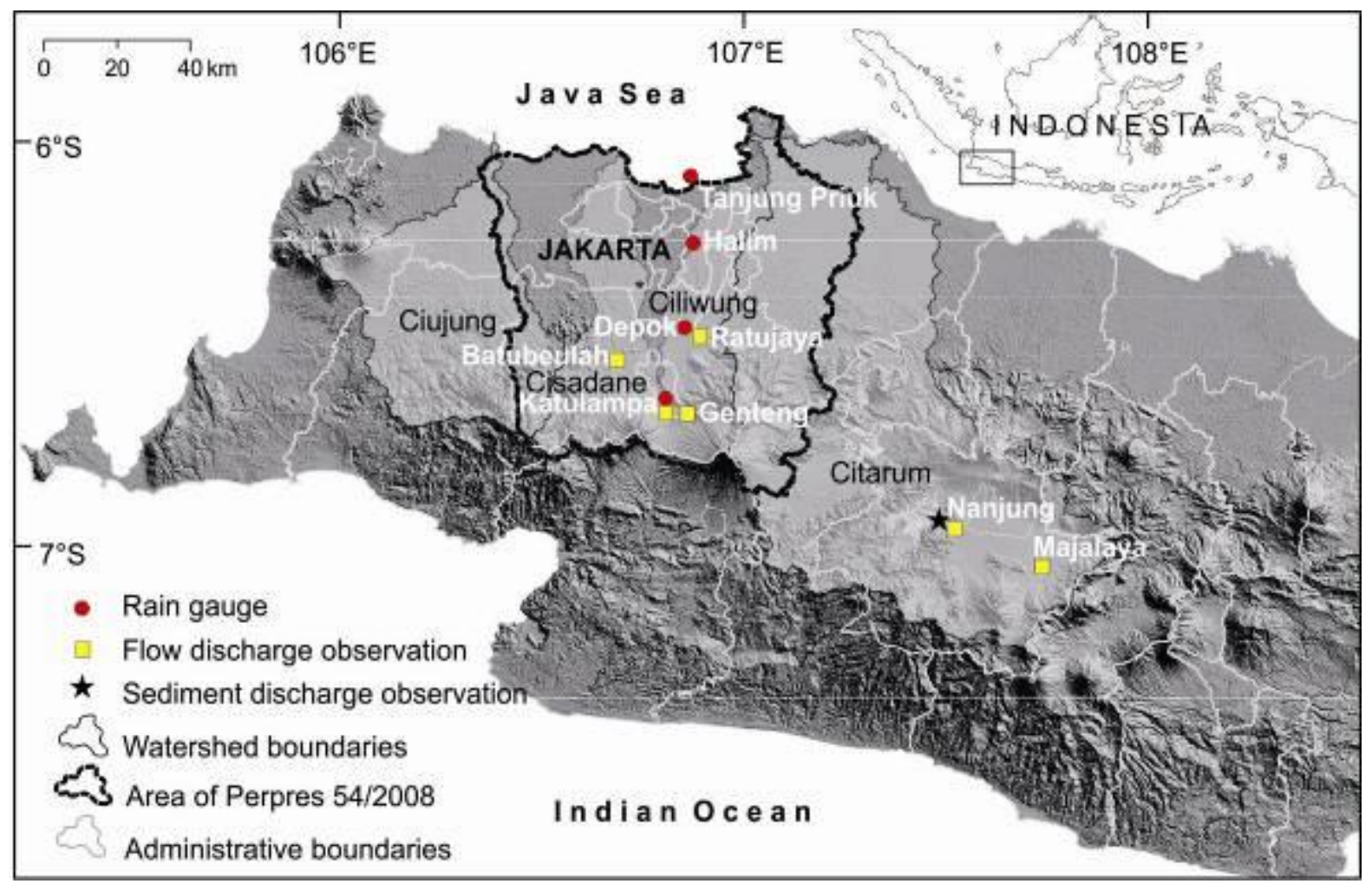

Figure 1. Ciujung, Cisadane, Ciliwung and Citarum watersheds and the area covered by Perpres 54/2008, comprising of Jakarta municipal area and Bogor, Depok, Tangerang, Bekasi and Cianjur districts

Table 1. Key characteristics of the watersheds studied in this paper

\begin{tabular}{lcccc}
\hline \multicolumn{1}{c}{ Characteristics } & Ciujung & Cisadane & Ciliwung & Citarum \\
\hline Dimensions & & & & \\
Area $\left(\mathrm{km}^{2}\right)$ & 2,809 & 1,726 & 1,147 & 8,058 \\
Average elevation (m) & 223 & 345 & 252 & 526 \\
Average slope $\left({ }^{\circ}\right)$ & 5.2 & 5.5 & 4.4 & 5.9 \\
\% area of slope $>30^{\circ}$ & 0.27 & 0.9 & 0.53 & 0.73 \\
\hline Land cover 2005 (in \%) & & & & \\
Forest & 38 & 25 & 9 & 20 \\
Agricultural & 55 & 57 & 29 & 68 \\
Built-up & 8 & 17 & 62 & 13 \\
\hline
\end{tabular}

\subsection{Models and data}

The method used in this study involves the spatial modeling of the water balance and sediment yield. The spatial water balance model, STREAM (Spatial Tools for River Basins and Environmental and Analysis of Management Option), is used for river discharge computation (Aerts et al. 1999), and SDAS (Spatial Decision Assistance of Watershed Sedimentation) is used for simulating erosion and the total sediment exported by a watershed system, i.e. sediment yield (Poerbandono et al. in review). Several data sources are required to simulate hydrological processes with STREAM and SDAS. Here we consider a Digital Elevation Model (DEM), precipitation and temperature data, and land cover data. We used the $30 \mathrm{~m} \times 30 \mathrm{~m}$ spatial resolution ASTER global DEM (GDEM) to derive the river network model and for watershed delineation.

We retrieved monthly precipitation and temperature time-series from January 1901 to December 2005, at a $30^{\prime} \times 30^{\prime}$ spatial resolution from the Climate Research Unit (CRU), University of East Anglia, United Kingdom (New et al. 2002); this dataset is known as CRU TS 3.0. We then downscaled the CRU TS 3.0 dataset to a $10^{\prime} \times 10^{\prime}$ spatial resolution (Bouwer et al. 2004). Firstly, the low resolution 
$\left(30^{\prime} \times 30^{\prime}\right)$ climate time-series datasets were simply resampled onto a higher resolution $\left(10^{\prime} \times 10^{\prime}\right)$ grid. Secondly, these resampled time-series $\left(10^{\prime} \times 10^{\prime}\right)$ were statistically downscaled by using change factors (for temperature additive and for precipitation multiplicative) to correct for the difference in mean monthly precipitation and temperature between CRU TS 3.0, and the higher resolution monthly climatological dataset CRU TS 2.0 (Mitchell et al. 2004). The latter dataset provides mean observed precipitation and temperature per month, for the period 1961-1990, at a horizontal resolution of $10^{\prime} \times$ 10 '. Verification of these downscaled precipitation data was carried out by comparing them with local observations, in terms of monthly average values (Poerbandono et al. 2009). Records of monthly rainfall depths from 1989 to 2002 are available from four observation stations: Tanjung Priok in the coastal side of Cisadane; Halim and Depok stations in the middle section of Ciliwung; and Katulampa in the upper part of Cisadane. We examined the bias in magnitudes of precipitation data with respect to observations. There is large bias at Tanjung Priok (84\%), yet we found very small bias (1\%) at Halim, which is located very closeby, $6 \%$ at Depok, and $-20 \%$ at Katulampa. On average, for the observed precipitation data used in this study, we found the gridded precipitation datasets used here to be $18 \%$ higher than the observed precipitation data.

Land cover maps for various years and classifications, and from various sources (Table 2), were used for the computation period. Here, land cover maps from 1891, 1950, 1963, 1980, 1987, and each year from 2001 to 2005 were used to generate land cover maps for the model input. The land covers are categorized into forest, agricultural, and built-up area. We simulated both river discharge and sediment yield for the period 1901-2005. For the computation of river discharge, we used a monthly time-step and sediment yield is computed on an annual basis. All data were resampled to a horizontal resolution of $100 \mathrm{~m} \times 100 \mathrm{~m}$ for discharge computation using STREAM, and to a horizontal resolution of $30 \mathrm{~m} \times$ $30 \mathrm{~m}$ for erosion rate and Sediment Delivery Ratio computation using SDAS. It should be noted that the use of land cover data from heterogeneous sources may result in biases in the steadiness of its natural succession. This might lead to discontinuity of the degradation sequence, particularly if individual grid cells are examined. However, generic succession and the trend of change of land cover can still be detected.

Table 2. Sources of land cover data

\begin{tabular}{cllc}
\hline No. & \multicolumn{1}{c}{ Title of map } & \multicolumn{1}{c}{ Source } & Year \\
\hline 1. & Natural forest cover of Java & Whitten et al. (1996) & 1891 \\
2. & Vegetation of Indonesia & US Department of Forest Service & 1950 \\
3. & Land cover map of Java and Madura & Food and Agriculture Organization & 1963 \\
4. & Land cover map & Ministry of Interior Indonesia & 1980 \\
5. & Natural forest cover of Java & Whitten et al. (1996) & 1987 \\
6. & MODIS land cover type product & Wei et al. (2009) & $2001-2005$ \\
\hline
\end{tabular}

\subsubsection{Computation of river discharge - STREAM}

The core of the STREAM instrument is a Geographic Information System (GIS) based rainfall-runoff model that allows for the computation of water availability and runoff per grid cell (Aerts et al. 1999, Aerts et al. 2006, Ward et al. 2007, Ward et al. 2008, Ward et al. 2011b). STREAM describes the hydrological cycle of a drainage basin as a series of storage compartments and flows. It calculates the water balance per grid cell using the Thornthwaite equation for potential evapotranspiration (Thornthwaite 1948) and the Thornthwaite \& Mather equations for actual evapotranspiration (Thornthwaite \& Mather 1957). Following this, storage of water in a grid cell is estimated according to the difference between evapotranspiration and precipitation. Runoff per time step is calculated according to the excess of water in each grid cell and baseflow from groundwater storage. The runoff is routed through the catchment to a river outlet based on a DEM. The main inputs to the model are climate data (maps of precipitation and temperature), a DEM, and land cover maps. We used land cover data as a proxy for the soil water holding capacity. A look-up table from Aerts et al. (1999) was used for the conversion of types of land cover into WATERH and crop factor (CROPF), which control respectively the capability of soil to retain water, and evapotranspiration. This approach is suggested in Aerts et al. (2005). Whilst it would be preferable to use actual measured data on soil water holding capacity (WATERH), STREAM is known to be relatively insensitive to changes in this parameter. A 
sensitivity test was carried out to examine the effect of WATERH on the simulated discharge. It is found that altering the WATERH factor by $50 \%$ (increase or decrease) led to just a $10 \%$ increase or decrease in simulated discharge. The calibration of STREAM for West Java is documented in Poerbandono et al. (2009). In the calibration, we used observed rainfall in the Cisadane and Cilwung watersheds, and observed river discharge from the upper Citarum, Cisadane, and Ciliwung watersheds. Four rainfall observation stations were used, with data for the period 1981 to 2002. For discharge, six gauging stations were used, with lengths of record varying from nine to 18 years. The calibration of STREAM considers optimum multipliers of crop factor, slope, water holding capacity, heat, and the ratio of direct and delayed runoff. The accuracy of STREAM was evaluated according to the agreement of computed and observed river discharge at the gauging stations: the difference in mean annual discharge between the computed and observed data ranged between $-8 \%$ and $5 \%$. In Figure 2, hydrographs of computed and observed discharges on a monthly basis are shown.
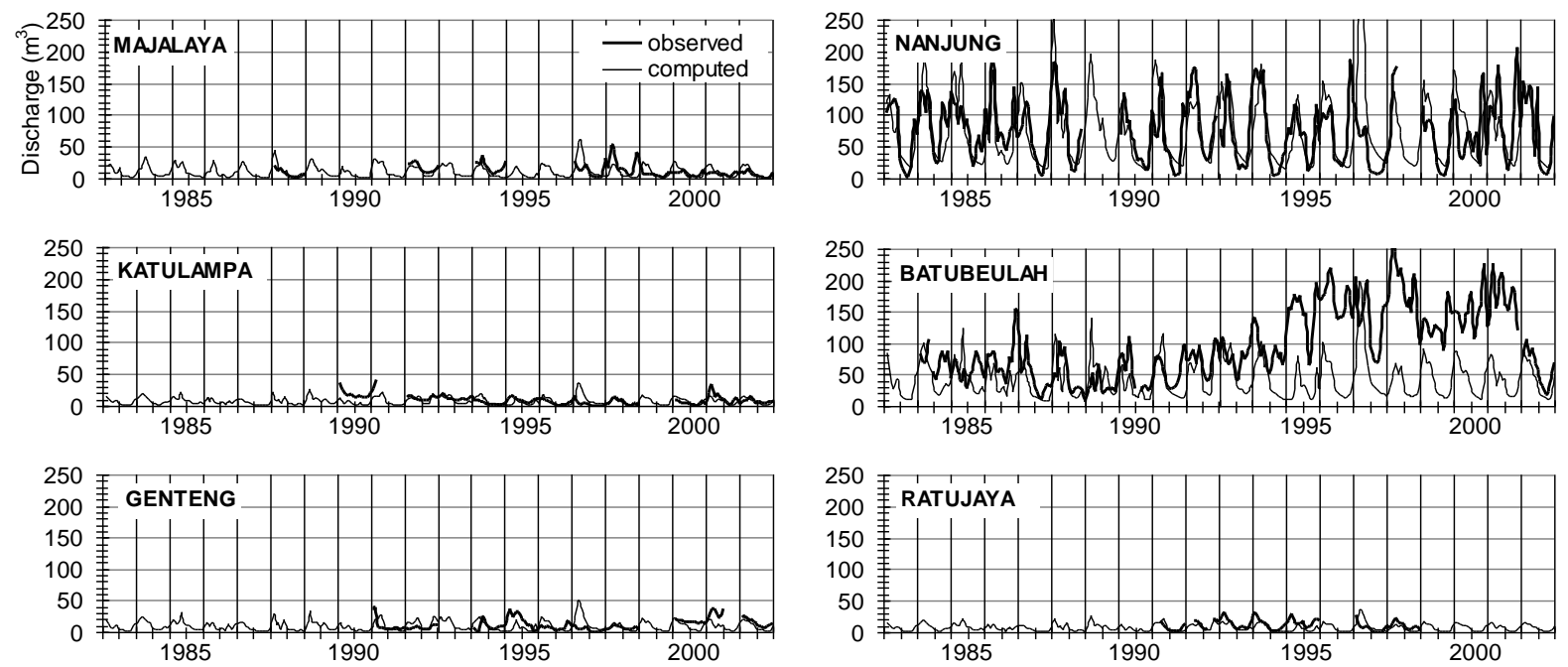

Figure 2. Monthly hydrographs of observed and computed discharges (Poerbandono et al. 2009)

\subsubsection{Computation of sediment yield - SDAS}

SDAS calculates sediment yield as a product of the erosion rate in each grid-cell and the Sediment Delivery Ratio (SDR) for each spatial unit (Poerbandono et al. in review). A spatial unit is the smallest element of a watershed considered in the computation, which could be equal to a sub-watershed or consist of at least one reach catchment. In our study, the smallest size assigned to the generation of a spatial unit is five pixels, which corresponds to an area of approximately $450 \mathrm{~m}^{2}$. SDAS calculates the erosion rate, which is controlled by topography (i.e. slope, flow length), soil type, rainfall, and type of land cover. In SDAS, the rate of erosion is determined according to the Universal Soil Loss Equation (USLE) (Wischmeier \& Smith 1978). Examples of input maps of soil, precipitation, and land cover are shown, respectively in Figures 3, 4, and 5. 


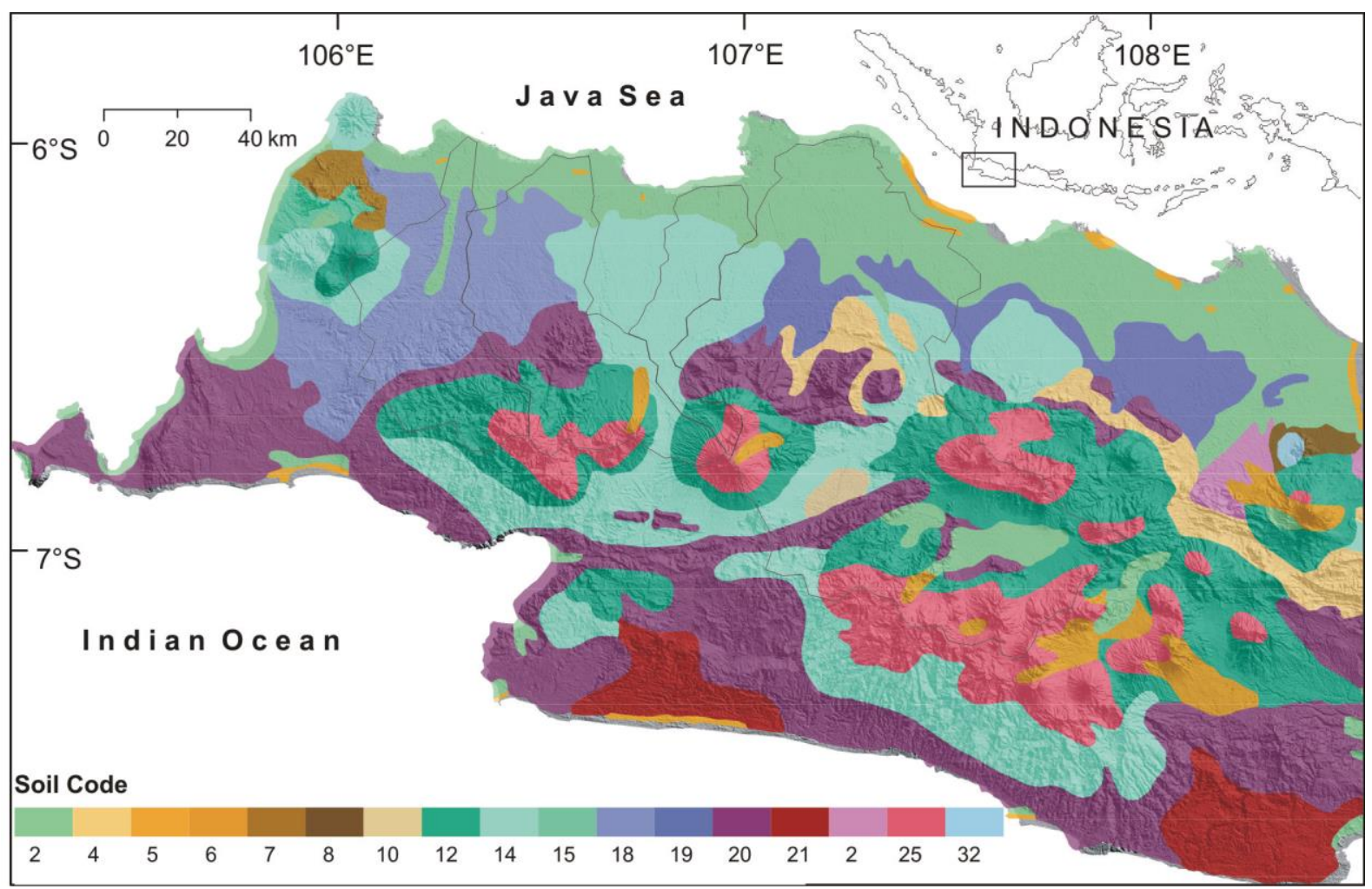

Figure 3. Soil type map, i.e. $2=$ alluvial, 4,5,6,7=regosol, $8=$ regosol and latosol, $10=$ grumusol, $12=$ latosol and andosol, 14,15=latosol, 18,19=red-yellow podzolic, $20=$ complex of redyellow podzolic, latosol and lithosol, $21=$ red-yellow mediterranean and grumosol, $23=$ redyellow mediterranean, grumosol, and regosol, 25=andosol, 32=complex of red-yellow mediterranean and lithosol

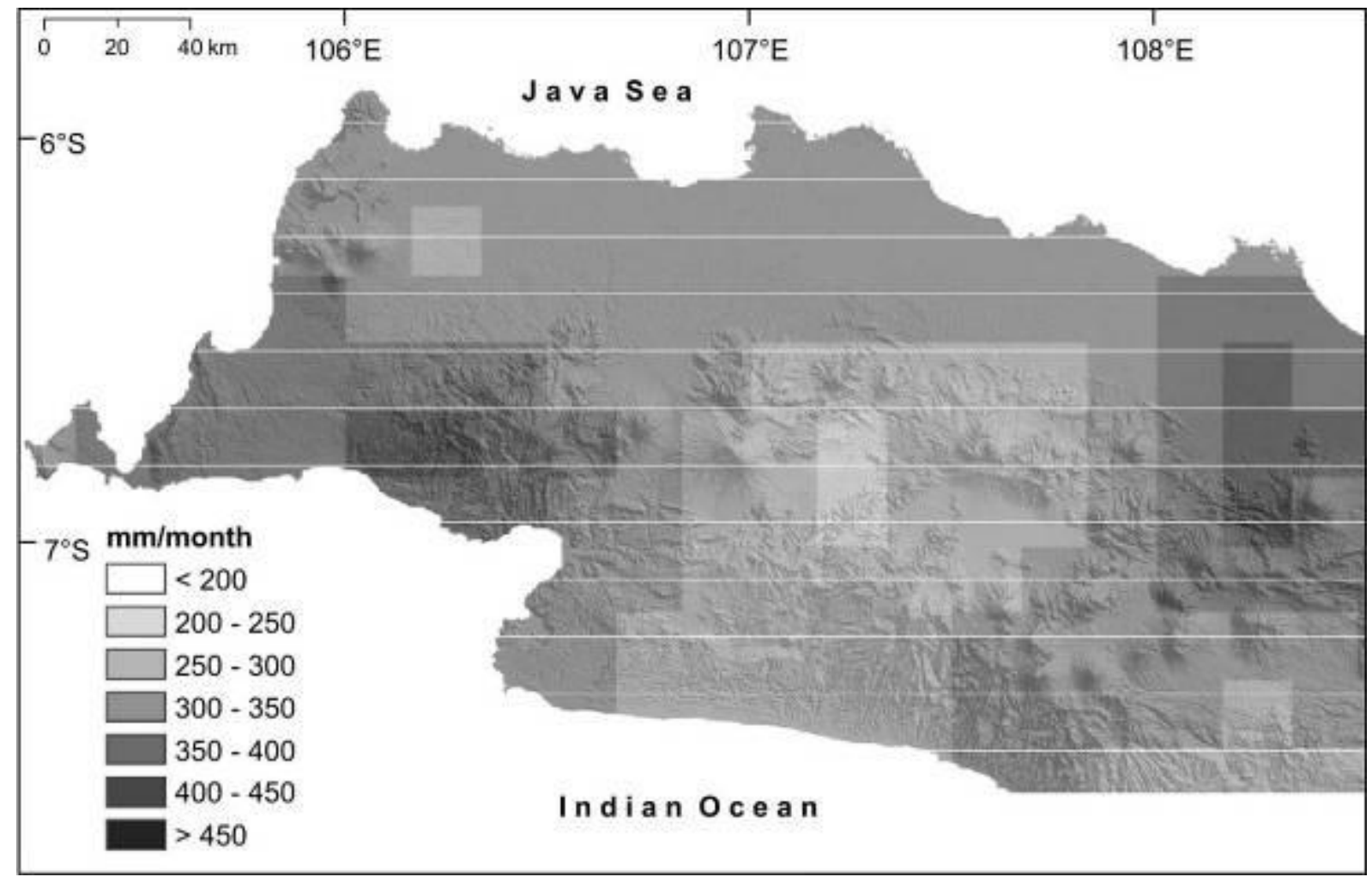

Figure 4. Sample of rainfall input map taken from February 2005 


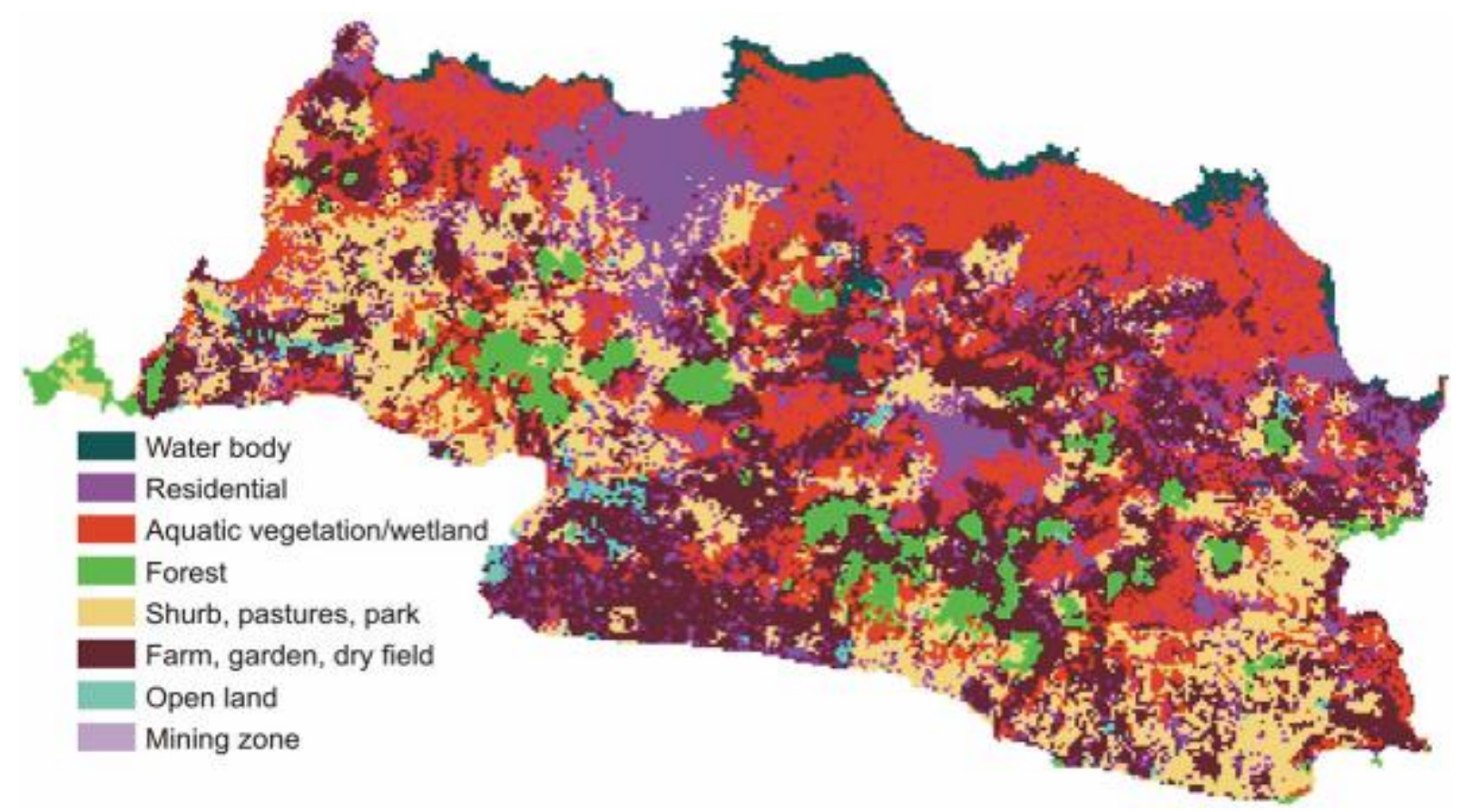

Figure 5. Sample of land cover input map from 2004

SDR is inversely proportional to sediment resident time in the river network and hillslope (Sivapalan et al. 2002, Lu et al. 2003) and calculated in SDAS according to rainfall, slope, sediment size, soil type, and land cover. In SDAS, land cover is used to generate the so-called $C$-factor map, where various types of land covers are indexed according to their erodibility. SDAS exports calculation results as gridded erosion rates and sediment yields. This allows for the spatial identification of specific locations (i.e. spatial units) in the watershed contributing to the total yield at the outlet. SDAS was set up and calibrated against observed data at the outlet of the upper Citarum catchment, i.e. the Nanjung measuring station (Poerbandono et al. in review). Field observations of total annual sediment yields are available for 1976, 1981, 1993, 2003, and 2004 (Poerbandono et al. 2006): the mean difference in annual sediment yield between computed and observed data is $7 \%$. The calibration of SDAS was carried out against observed sediment yields. This involved the adjustment of several parameters comprising of adjustment factors for input data, i.e. precipitation, land cover, and several constants comprising of flow depths on hillslope and network channel, sediment settling velocity, as well as mean and effective rainfall duration. From the calibration, it is known that all factors and constants are considered to be unchanged over time except for the flow depths on hillslope which should be altered with changes of land cover. In Figure 6, we show a comparison between computed and observed sediment yield.

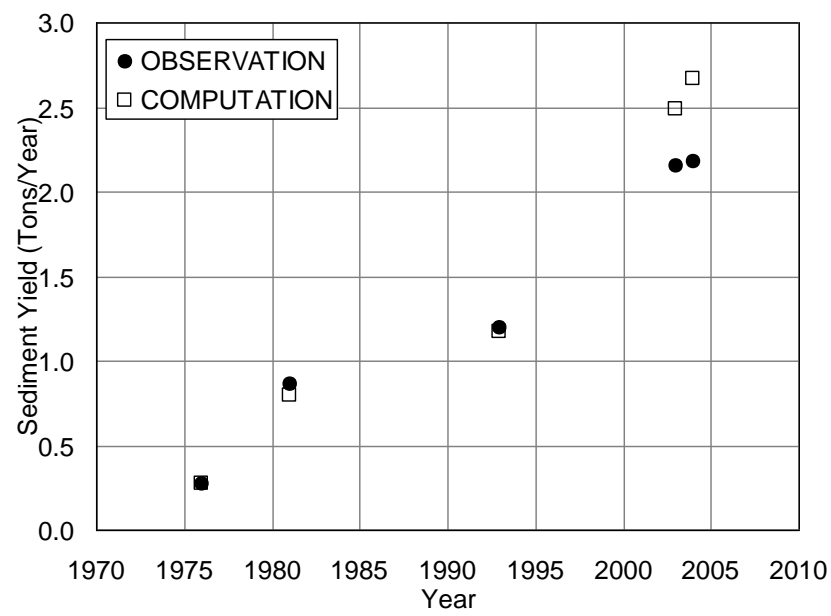

Figure 6. Computed and observed sediment yields (Poerbandono et al. in review) 


\subsection{River discharge}

Mean monthly river discharge for the outlets of the four watersheds studied are shown in Figure 7. As the figure shows, the Citarum watershed contributes the most water to the Jakarta Bay. Linear trends of mean annual discharge for the four watersheds, and the statistical significance of trends assessed using the Mann-Kendall test (Helsel \& Hirsch, 1992), are shown in Table 3. The trends are shown for the last 105-, 55-, 30-, and 15-year periods. Positive trends of computed river discharge are seen in all watersheds and periods, with the trends generally becoming stronger for the more recent period (i.e. the last fifteen years) compared to the last 105-years. For the entire period 1901-2005, the trends are not statistically significant for any of the watersheds. However, for the more recent periods, several statistically significant trends were found.

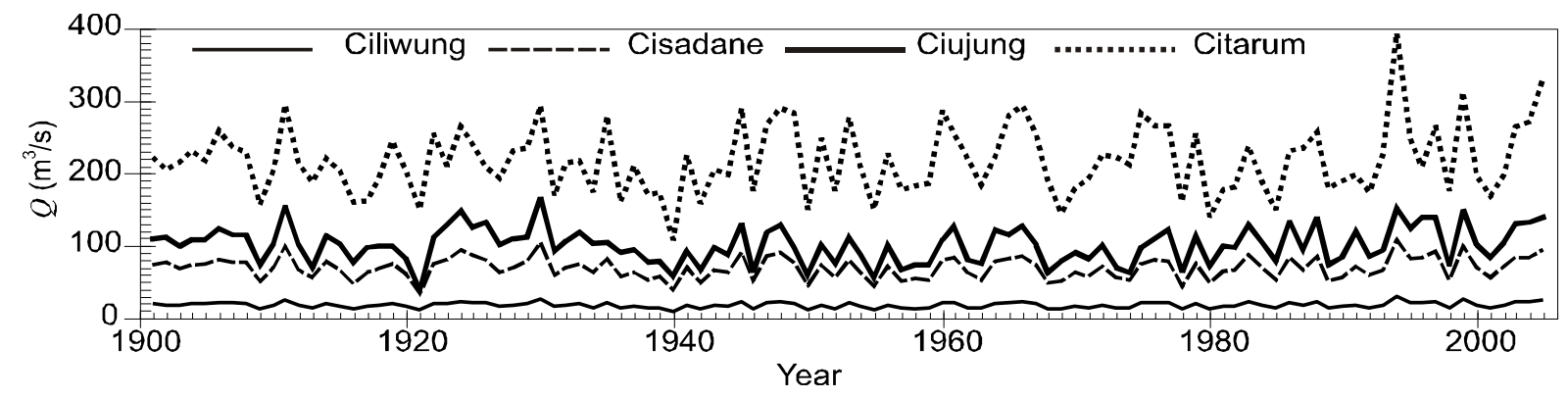

Figure 7. Monthly average computed river discharge $(Q)$ over the period 1900-2005 for the four watersheds used in this study.

Table 3. Linear trends of computed river discharge in $\mathrm{m}^{3} \mathrm{~s}^{-1} /$ month over the time-periods shown.

\begin{tabular}{lcccccccc}
\hline \multirow{2}{*}{ Location } & \multicolumn{1}{c}{$1901-2005$} & \multicolumn{2}{c}{$1950-2005$} & \multicolumn{2}{c}{$1975-2005$} & \multicolumn{2}{c}{$1990-2005$} \\
\cline { 2 - 9 } & Trend & LoS* & Trend & LoS* & Trend & LoS* & Trend & LoS* \\
\hline Ciujung & 0.04 & NS & 0.70 & 0.01 & 0.92 & 0.1 & 1.38 & NS \\
Cisadane & 0.02 & NS & 0.33 & 0.05 & 0.50 & NS & 0.94 & 0.1 \\
Ciliwung & 0.01 & NS & 0.10 & 0.01 & 0.13 & 0.1 & 0.25 & 0.1 \\
Citarum & 0.19 & NS & 0.60 & NS & 1.33 & NS & 3.18 & NS \\
\hline
\end{tabular}

*LoS=Level of Significance

Figure 8 shows the annual hydrographs for different periods of $\sim 20$-year monthly river discharge, for each watershed. For all watersheds, the highest river discharges can be seen for the period 1981-2005; the increase in this period compared to the previous period (1961-1980 period) ranges between 3 and $18 \%$, depending on the watershed. Generally, the river discharges in the most recent period are particularly high (compared to the previous periods) during the first half of the calendar year, which is also the period in which several of the recent major floods in Jakarta City have taken place. In Figure 9, we show the change in computed annual river discharge for each $\sim 20$ year period, relative to the period 1901-1920. Relative influences of climate and land use change on these simulated changes in discharge are discussed in Section 3.3. 


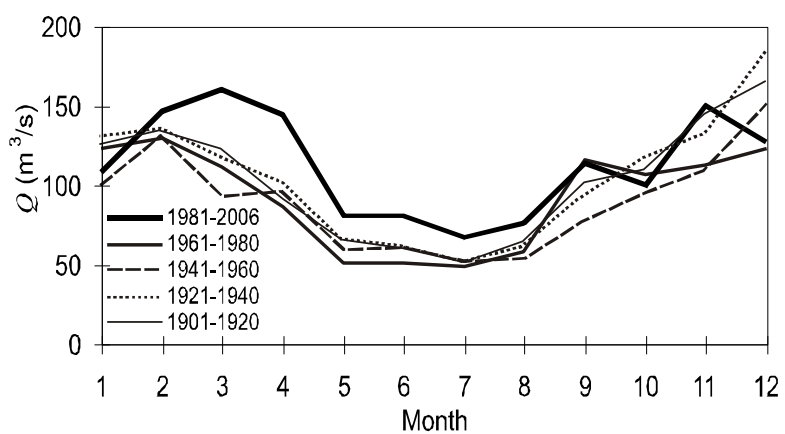

(a) Ciujung

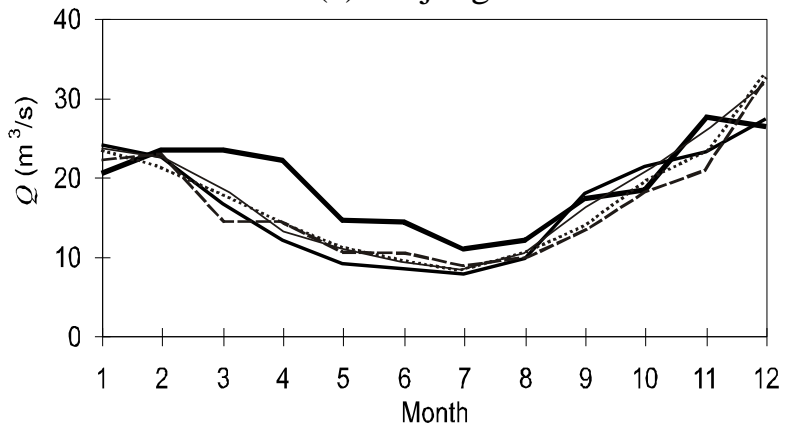

(c) Ciliwung

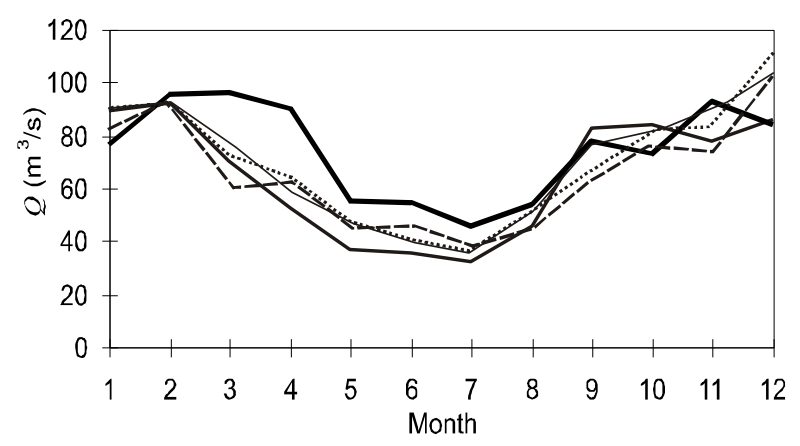

(b) Cisadane

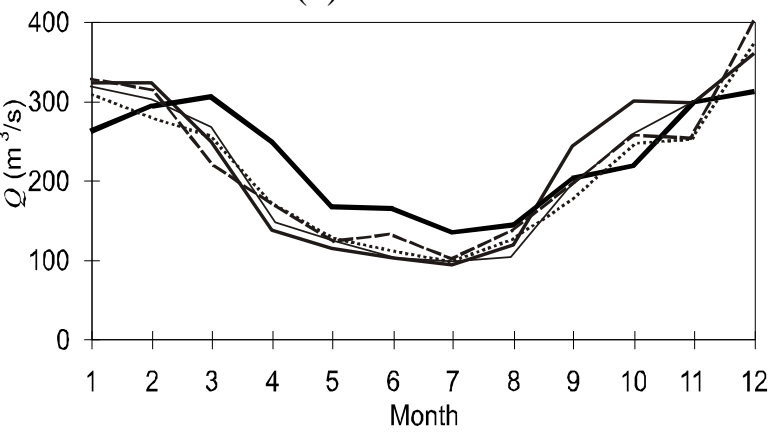

(d) Citarum

Figure 8. Monthly average river discharge $(Q)$ per $\sim 20$-year period for: (a) the Ciujung watershed; (b) the Cisadane watershed; (c) the Ciliwung watershed; and (d) the Citarum watershed.

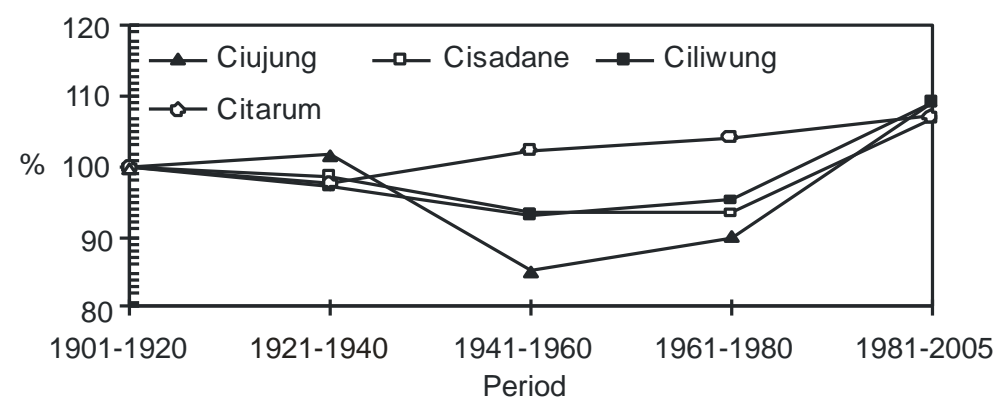

Figure 9. Changes of computed mean annual river discharge relative to the period 1901-1920

We investigated cycles in the time-series of computed monthly mean river discharge using the Fast Fourier Transform (FFT) technique (Duhamel et al. 1990) to transform time-series data into periodseries data. This transform allows the identification of cycles in the time-series data. The period series of computed river discharge are shown in Figure 10. Cyclic periodicity of river discharge can be seen at 1-, 4-, 6-, 10-, and 18-year periods. The 1-year period is related to the annual cycle. The medium period cycles may be related to the El-Niño Southern Oscillation (ENSO), which has been shown to be strongly linked with precipitation in several parts of Indonesia (Aldrian \& Susanto 2003, Aldrian et al. 2007, Hendon 2003, Qian et al. 2010), and through teleconnections over large parts of the globe (Ward et al. 2010, 2014). 


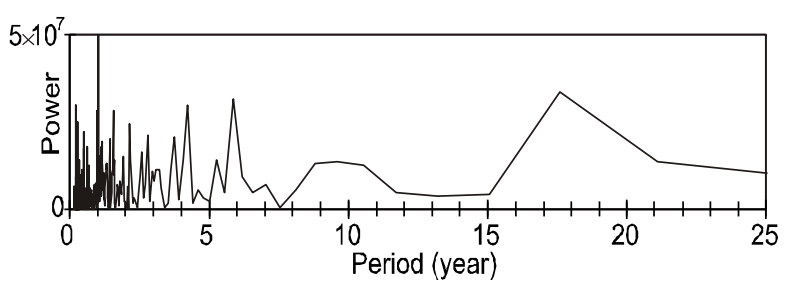

(a) Ciujung

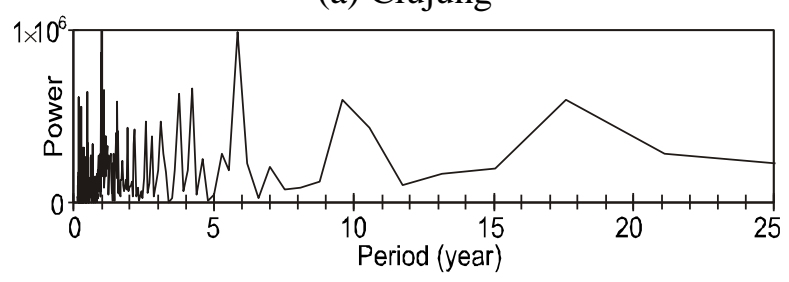

(c) Ciliwung

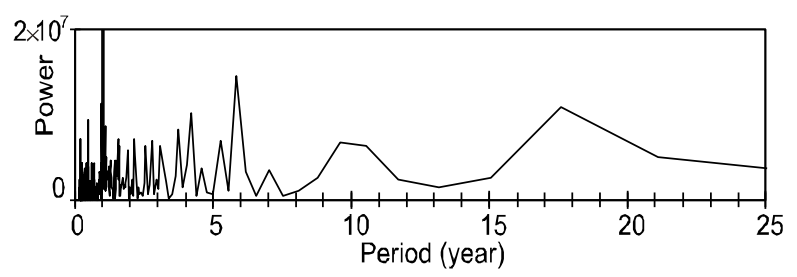

(b) Cisadane

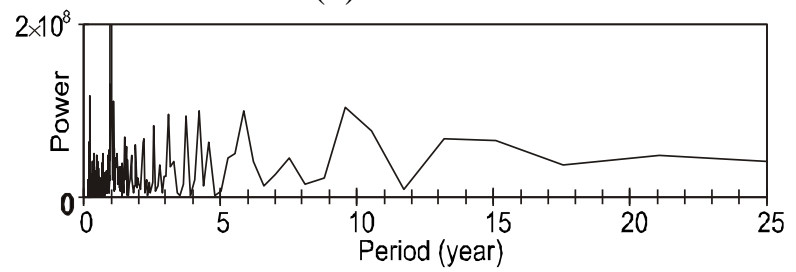

(d) Citarum

Figure 10. Cycle period of computed river discharge, based on FFT analysis

\subsection{Sediment yield}

Sediment yield was computed with an annual time-step from 1901 to 2005; annual values of sediment yield are shown in Figure 11. From Figure 11 one can observe that the largest contribution of sediment to the sea around Jakarta (of the case study watersheds studied) is from the Citarum watershed. In Table 4, slopes of linear trends (and significance levels of the Mann-Kendall test) of annual sediment yield are listed for the last 105-, 55-, 30-, and 15-year periods. Over the entire computation period (1901-2005), the increasing trend is significant for all basins; this is also the case for the most recent period (1990-2005). In the Cisadane watershed, negative trends are found over the periods 1950-2005 and 1975-2005. However, these do not reach statistical significance. For the Ciliwung watershed, the trends are not statistically significant over the periods 1950-2005 and 1975-2005. Generally the increasing trends observed are highest in the period 1990-2005.

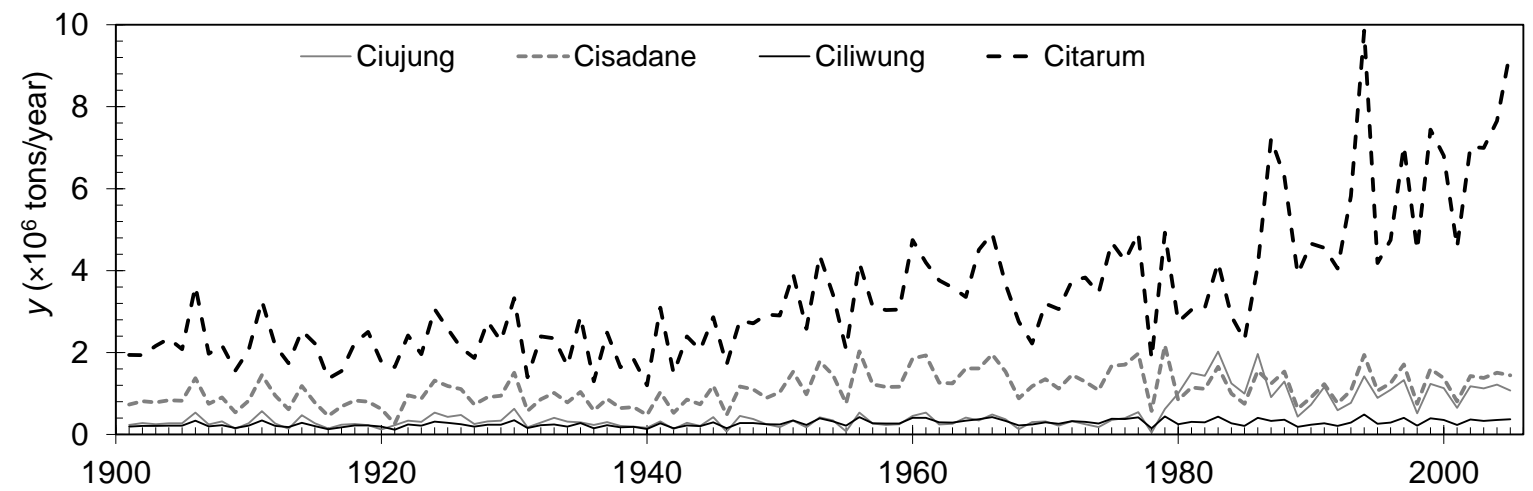

Figure 11. Mean annual sediment yield $(y), 1901-2005$

Table 4. Linear trend of computed mean annual sediment yield in $10^{3}$ tons/year

\begin{tabular}{lcccccccc}
\hline \multirow{2}{*}{ Location } & \multicolumn{1}{c}{$1901-2005$} & \multicolumn{2}{c}{$1950-2005$} & \multicolumn{2}{c}{$1975-2005$} & \multicolumn{2}{c}{$1990-2005$} \\
\cline { 2 - 9 } & Trend & LoS* & Trend & LoS* & Trend & LoS* & Trend & LoS* \\
\hline Ciujung & 9 & 0.01 & 20 & 0.01 & 10 & NS & 16 & NS \\
Cisadane & 6 & 0.01 & -3 & NS & -4 & NS & 23 & 0.1 \\
Ciliwung & 1 & 0.01 & 0 & NS & 0 & NS & 6 & 0.05 \\
Citarum & 42 & 0.01 & 68 & 0.01 & 141 & 0.01 & 200 & 0.01 \\
\hline
\end{tabular}

*LoS=Level of Significance

Besides assessing basin-scale change and trends in the time-series, the results of the sediment yield computation are presented spatially in Figure 7, in order to locate major sources of sediment. The maps are indicative of sediment yield in the early $20^{\text {th }}$ century (year 1901, Figure 12a) and in the early $21^{\text {st }}$ century (year 2005, Figure 12b). The aggregated statistics of the sediment yield maps are 
summarized in Table 5. Increased sediment yields during the latest 10 years contribute a major part of the overall increase during the entire 105 year period (see Table 5). For the Ciliwung and Cisadane watersheds, most of the increase in sediment yield has occurred during the latest 10 year period (19952005). Sediment yield has increased in all watersheds, with extremely large increases computed in the Citarum and Ciujung watersheds. Over the period 1901 to 2005, a large proportion of the increased sediment yield is derived from erosion in the upper areas of the catchment, where the slope is steepest. Based on the erosion classification of Maione et al. (2000), we refer to sediment yield (y) up to 3,000 tons $/ \mathrm{km}^{2} /$ year as "low to medium", and sediment yield exceeding 3,000 tons $/ \mathrm{km}^{2} /$ year as "medium to high". Table 6 shows the percentage of land in each basin for which the erosion is classed as low to medium or medium to high, for the years 1901 and 2005. In 2005, the Citarum watershed has the highest percentage of land area with medium to high erosion ( $8.4 \%$ of total area, see Table 6). For all watersheds, the results show a major increase in the area affected by medium to high erosion between the period 1901 and 2005; the largest increases in relative terms are in the Citarum and Ciujung watersheds.

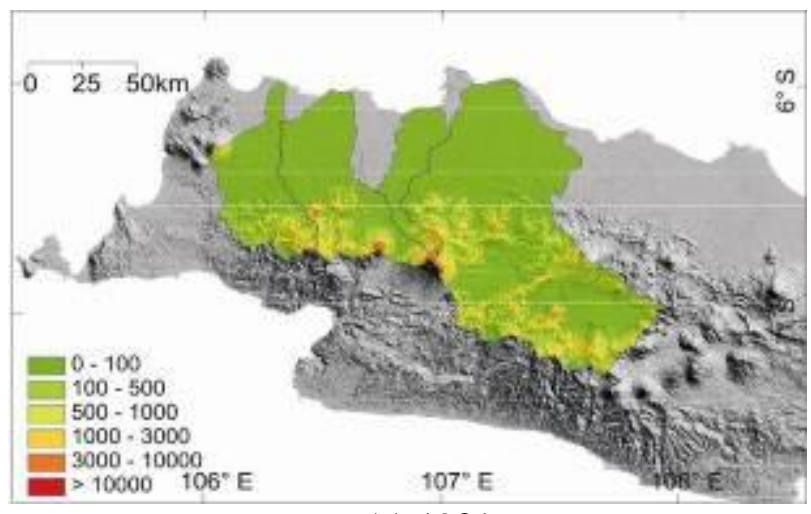

(a) 1901

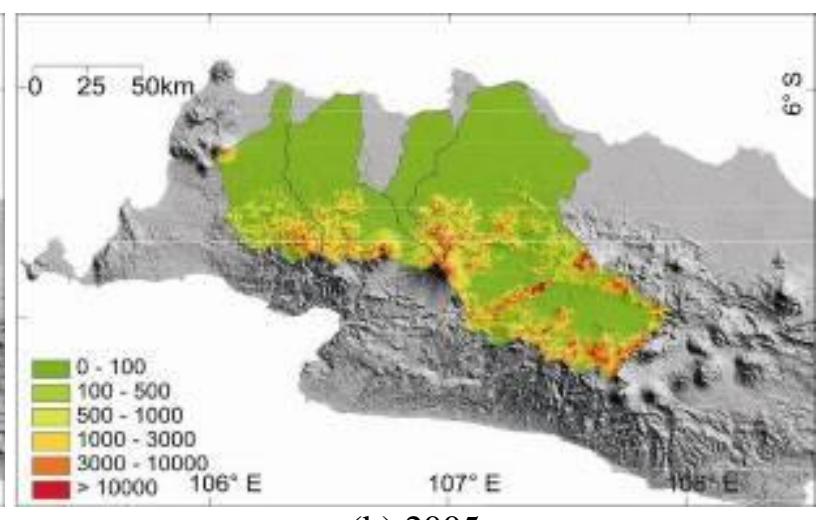

(b) 2005

Figure 12. Spatial distribution of mean annual sediment yield ( $y$, tons per $\left.\mathrm{km}^{2}\right)$ distribution for (a) 1901, and (b) 2005.

Table 5. Statistics of mean annual sediment yield per basin, in 1901, 1995 and 2005 (in tons)

\begin{tabular}{lrcrcccccc}
\hline \multirow{2}{*}{ Watershed } & \multicolumn{2}{c}{1901} & \multicolumn{2}{c}{1995} & \multicolumn{2}{c}{2005} & \multicolumn{2}{c}{$\Delta y_{\text {mean }}$} & \multirow{2}{*}{$\Delta 10 / 105^{*}$} \\
\cline { 2 - 9 } & \multicolumn{1}{c}{ Max } & Mean & \multicolumn{1}{c}{ Max } & Mean & Max & Mean & $1901-2005$ & $1995-2005$ & \\
\hline Ciujung & 4,518 & 171 & 4,432 & 356 & 28,078 & 513 & $200 \%$ & $44 \%$ & $22 \%$ \\
Cisadane & 9,351 & 273 & 7,129 & 293 & 16,888 & 487 & $78 \%$ & $66 \%$ & $84 \%$ \\
Ciliwung & 10,566 & 179 & 3,359 & 186 & 14,330 & 351 & $96 \%$ & $89 \%$ & $92 \%$ \\
Citarum & 6,485 & 204 & 26,025 & 385 & 103,900 & 917 & $350 \%$ & $138 \%$ & $40 \%$ \\
\hline
\end{tabular}

*Change of mean sediment yield in the latest 10 years (1995-2005) compared to that in the last 105 years (1901-2005)

Table 6. Percentage of area per watershed for which the erosion is low to medium or medium to high in 1901 and 2005 (in \% of total area of watershed)

\begin{tabular}{|c|c|c|c|c|c|c|c|c|}
\hline \multirow{2}{*}{ Erosion category } & \multicolumn{2}{|c|}{ Ciujung } & \multicolumn{2}{|c|}{ Cisadane } & \multicolumn{2}{|c|}{ Ciliwung } & \multicolumn{2}{|c|}{ Citarum } \\
\hline & 1901 & 2005 & 1901 & 2005 & 1901 & 2005 & 1901 & 2005 \\
\hline OW & 99.8 & 95.3 & 98.4 & 95.9 & 98.8 & 96.2 & 99.6 & 91.6 \\
\hline Medium to high $(y>3000)$ & 0.2 & 4.7 & 1.6 & 4.1 & 1.2 & 3.8 & 0.4 & 8.4 \\
\hline
\end{tabular}

The changes in sediment yield distribution between 1901 and 2005 (105 years) and between 1995 and 2005 (10 years) are shown spatially in Figure 13. Here, we see the largest increases of sediment yield predominantly in the upper parts of the Citarum watershed. Decreases in sediment yield can also be seen in some areas, particularly the middle areas of the Ciliwung and Cisadane watersheds. 


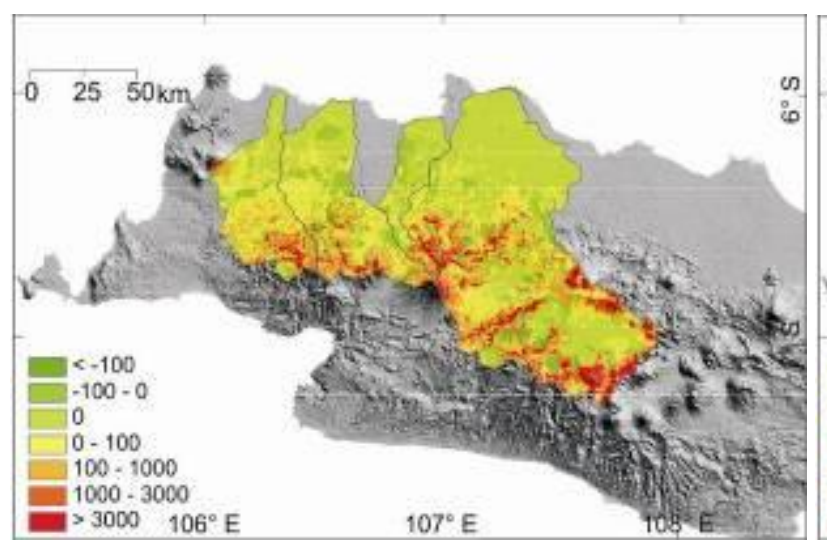

(a) 1901-2005

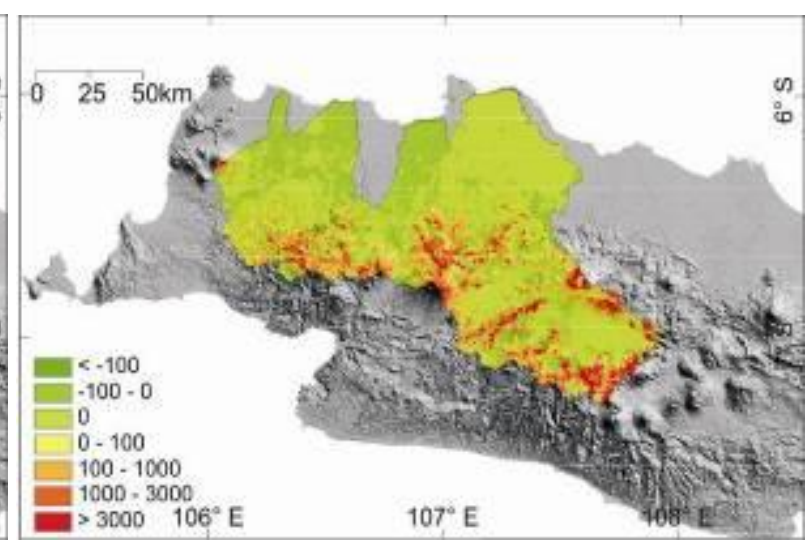

(b) 1995-2005

Figure 13. Spatial distribution of change in annual sediment yield $\left(\Delta y\right.$, tons per $\left.\mathrm{km}^{2}\right)$ between: (a) 1901-2005; and (b) 1995-2005

We also assessed cycles in the results of the sediment yield computations, using the same FFT analyses as for the river discharge results. Periodicities of sediment yield are shown in Figure 14, with similar periodicities as for the river discharge results, although the strength of those cycles is much lower than for the river discharge results (especially for the more frequent periods), suggesting that sediment yield may be less sensitive to inter-annual variations in climatic factors (i.e. rainfall) than the river discharge results.

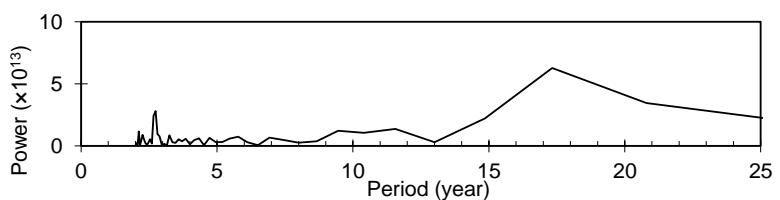

(a) Ciujung

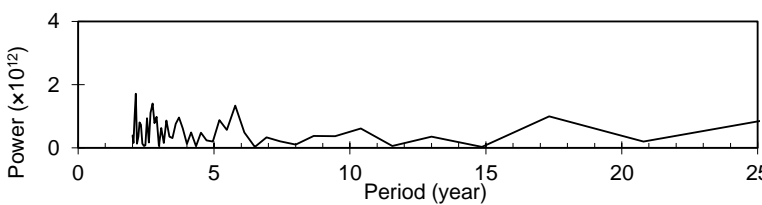

(c) Ciliwung

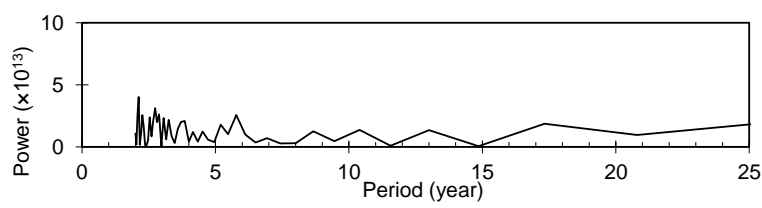

(b) Cisadane

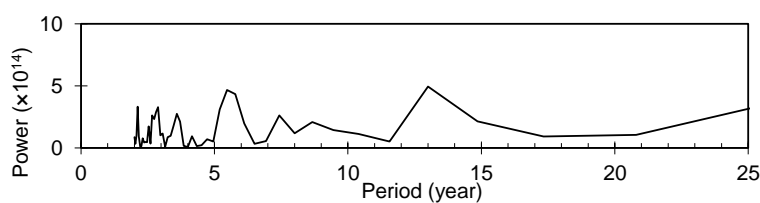

(d) Citarum

Figure 14. Cycle periods of computed sediment yield

The significant increases of computed sediment yields could be caused by several factors. The significant change of land cover input in the latest two decades is seen as the primary reason; the increase in sediment yield correlated well with the increase in the $C$-factor (i.e. watershed erodibility) in the same period. Precipitation is one of the inputs to the erosion, Sediment Delivery Ratio, and sediment yield model. In this study, we found that any positive trends in mean annual precipitation throughout the period 1901-2005 were not statistically significant, which also suggests that changes in land cover had a dominant effect on the increase in sediment yield. As mentioned in the section on river discharge, El-Niño Southern Oscillation (ENSO) events are known to have significant impacts on the climate of the region. In the FTT analysis we see similar periodic cycles in both the river discharge and sediment yield data; these may be related to ENSO, although further research is needed to examine this. The strength of the periodic cycles is greater for river discharge than for sediment yield.

\subsection{Individual role of climate and land cover changes on river discharge and sediment yield}

In STREAM, changes in input data for precipitation, temperature, and land cover lead to changes in river discharge. In order to examine the individual effects of each of these three variables, we carried out further computations using STREAM, whereby two variables were held constant at their values for the period 1901-1920, whilst the third variable was allowed to change over the period 1901-2005. Based on these computations, Figure 10 shows the individual contribution of changes in each 
parameter on river discharge, relative to the period 1901-1920. From Figure 15, it can be seen that the changes of precipitation, temperature, and land cover all have impacts on the river discharge. For all watersheds, the largest changes in the latest period (relative to the period 1901-1920) are due to changes in land cover. For all watersheds, changes in river discharge are also strongly influenced by an increase in precipitation during the most recent period. According to the computation results, over the course of the $20^{\text {th }}$ century (period of 1981-2005 relative to the period of 1901-1920), changes in precipitation have caused an increase of river discharge by up to $9 \%$. The computed increases in temperature, on the other hand, have contributed to decreased river discharge by up to 7\% (through increased evapotranspiration). The highest impact of $20^{\text {th }}$ century changes in precipitation and temperature on river discharge can be seen in the Ciujung watershed. The impacts of $20^{\text {th }}$ century land cover change on simulated discharge have been stronger than the impacts of climatic change over that period. Over the course of the $20^{\text {th }}$ century, the computed discharges increased by between $10 \%$ and $17 \%$ (depending on the basin) as a result of land cover change alone. The highest contributions of land cover change to increased discharge occurred in the Ciliwung (12\%) and Citarum (17\%) watersheds.

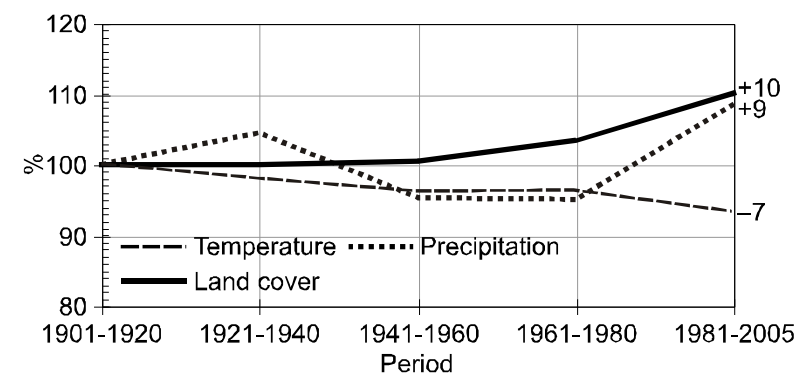

(a) Ciujung

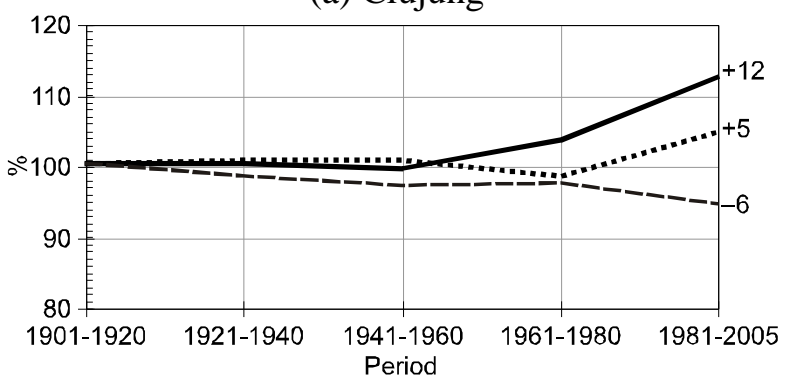

(c) Ciliwung

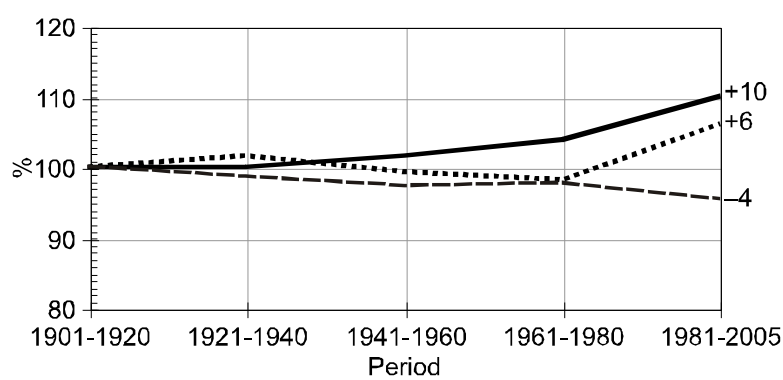

(b) Cisadane

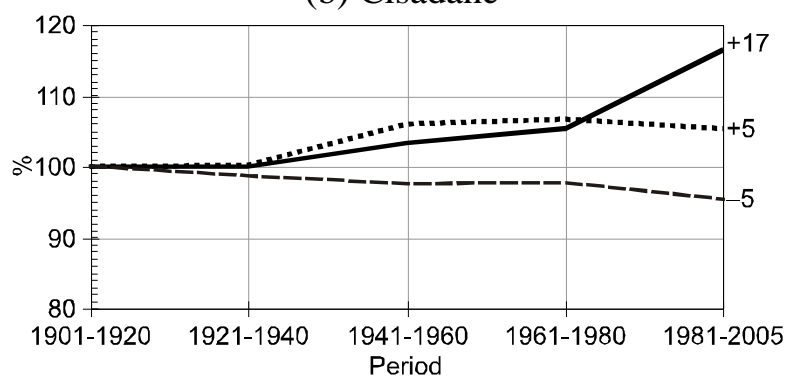

(d) Citarum

Figure 15. Individual effects of precipitation, temperature and land cover changes on river discharge relative to the period 1901-1920 (in \%)

Using SDAS, we applied an analogous approach to that used for river discharge to examine the individual effects of precipitation and land cover change on sediment yield over the course of the $20^{\text {th }}$ century (compared to the period 1901-1920); the results are shown in Figure 16. Whilst changes in both precipitation and land cover have caused increased sediment yield over the study period, the impact of land cover change has been greater. Especially in the latest 25 years, the increase in sediment yield due to land cover change is particularly large, with increases compared to the period 1901-1920 of 55\% and 59\% in the Ciliwung and Citarum watersheds respectively. 


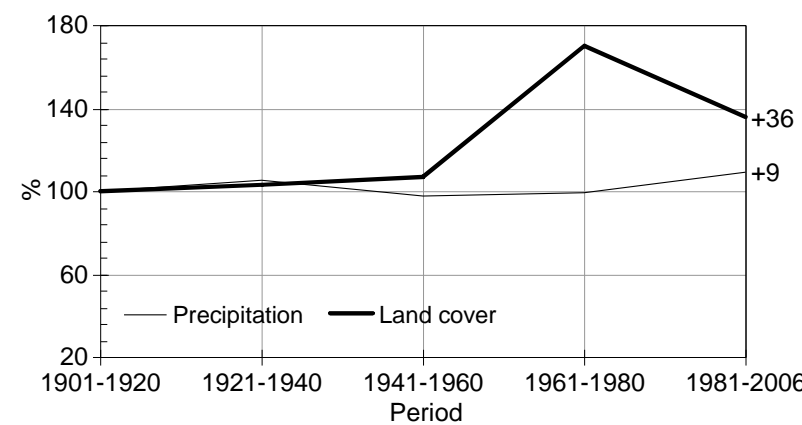

(a) Ciujung

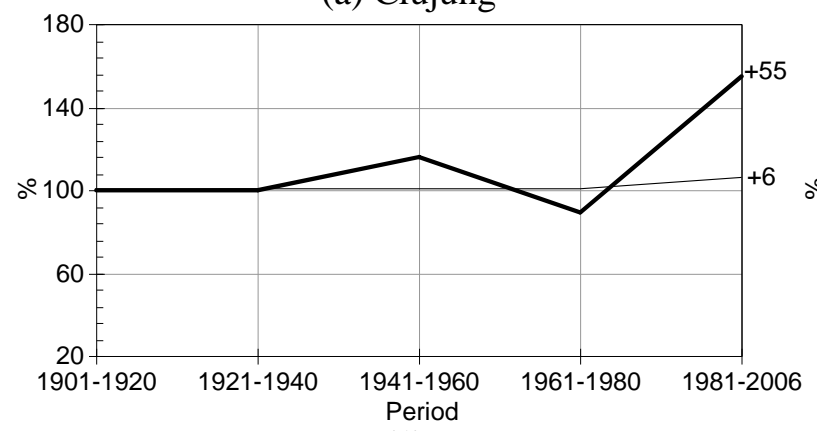

(c) Ciliwung

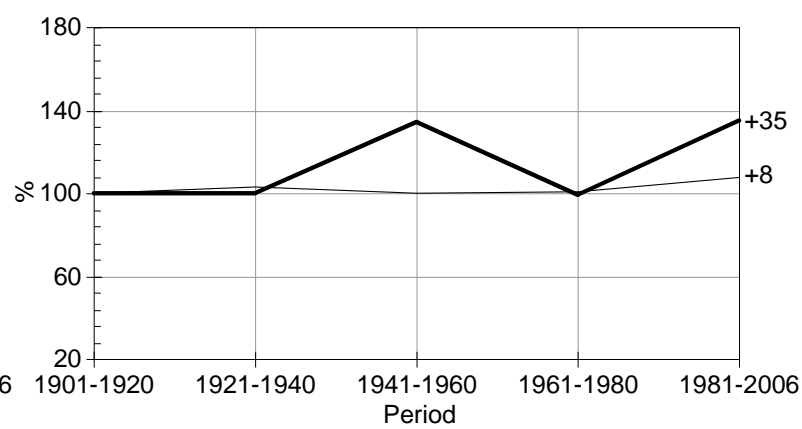

(b) Cisadane

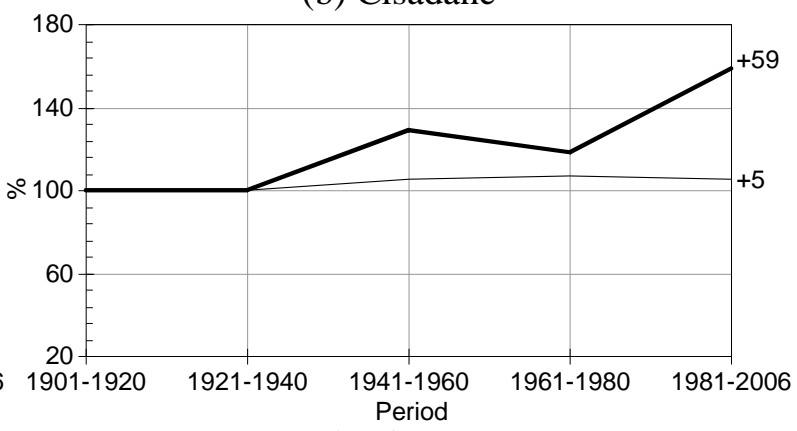

(d) Citarum

Figure 16. Individual effects of precipitation and land cover changes on sediment yield relative to the period 1901-1920 (in \%)

3.4 Computation of river discharge and sediment yield under the land cover planning scenario described in Perpres 54/2008

A theoretical land use plan for the Jabodetabek area is shown in Perpres 54/2008. Perpres 54/2008 is a reference policy for the implementation of development related to water and soil conservation, the availability of ground water and surface water, flood prevention, and economic development. One of the purposes of Perpres 54/2008 is to compensate anthropogenic pressures caused by changes in land cover. In this study, we examine the potential effect that a full implementation of the land cover plan as described in Perpres 54/2008 could have on river discharge and sediment yield. Only those watersheds that are fully covered by Perpres 54/2008 are considered, i.e. Ciliwung and Cisadane. Three evaluation points for each watershed were investigated: downstream, middle, and upper watersheds. Two scenarios of land cover were used (i.e. land cover according to the theoretical land cover plan Perpres 54/2008, and the actual situation). The recent land cover was generated based on the interpretation of MODIS imagery from 2007. The two scenarios of land cover were converted into CROPF and WATERH maps, for use in the STREAM model. The climate data used were mean monthly temperature and precipitation for the period 1961 to 1990 (CRU Climatology version 2.0 CRU CL 2.0) (New et al. 2002). CROPF and WATERH under the actual and Perpres 54/2008 scenarios are shown in Figures 17 and 18. The red line boundary indicates the coverage area of Perpres 54/2008. In our computations, a full implementation of Perpres 54/2008 leads to an overall average increase in WATERH by $2.02 \%$, and CROPF by $0.03 \%$, with respect to the actual condition. 


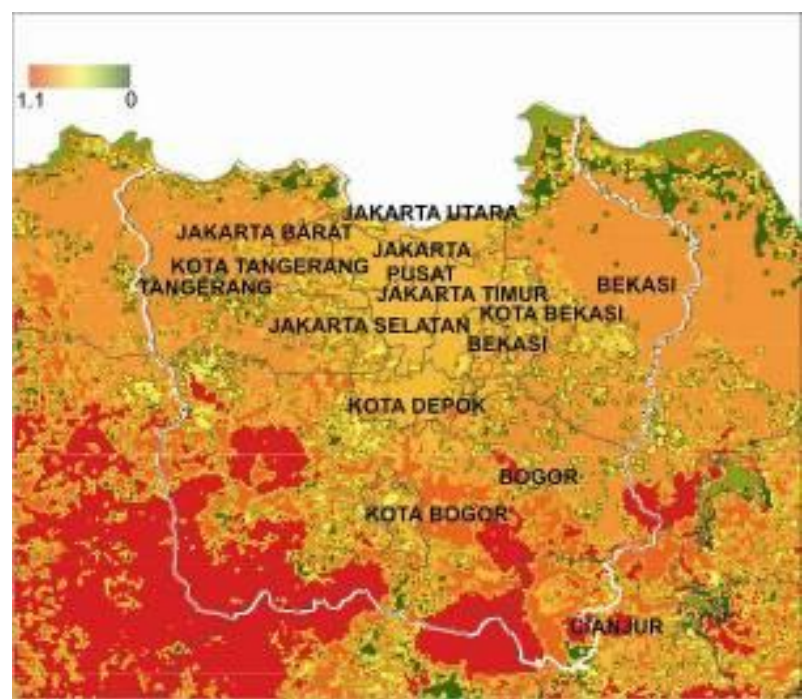

(a) Actual

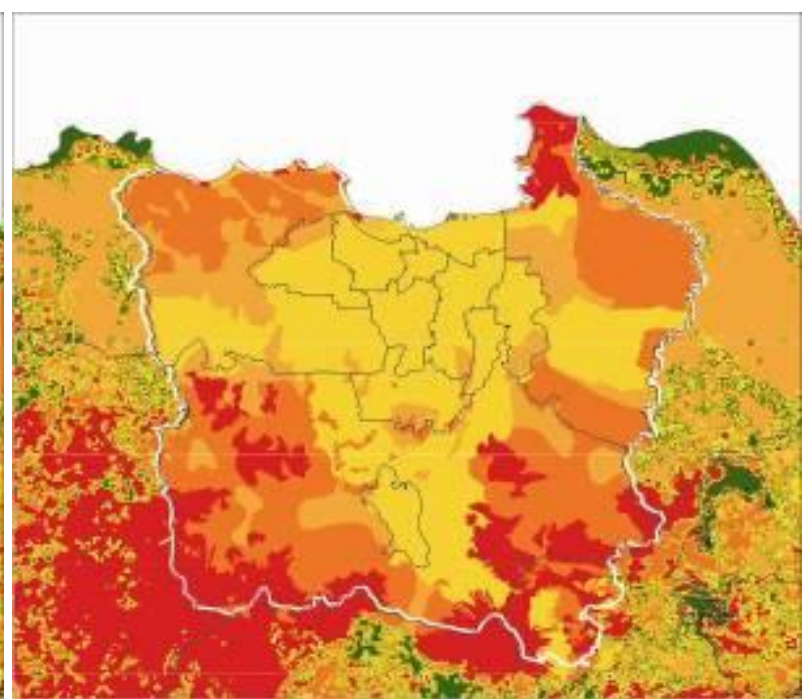

(b) Perpres 54/2008

Figure 17. Crop factor (CROPF) map for: (a) actual, and (b) Perpres 54/2008 scenarios

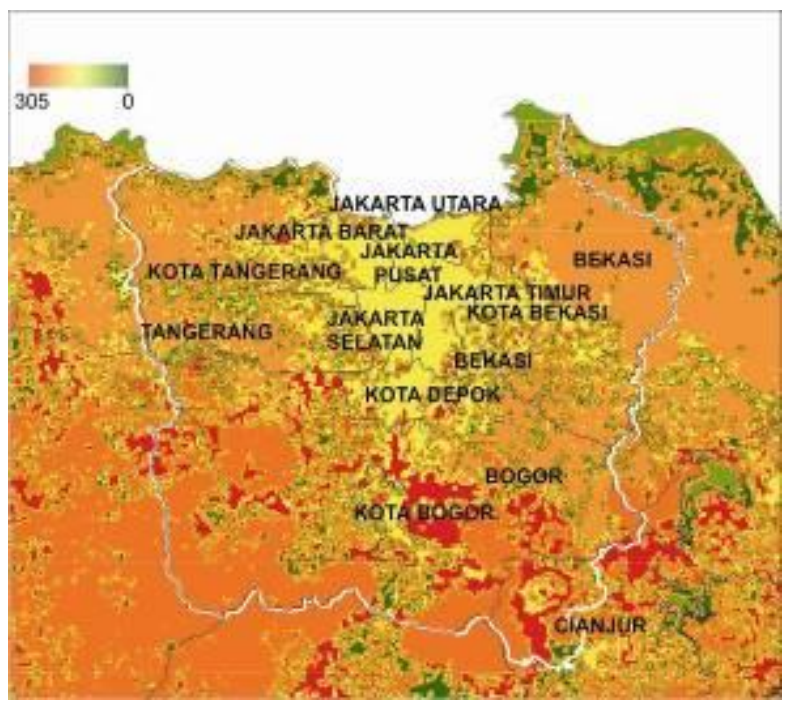

(a) Actual

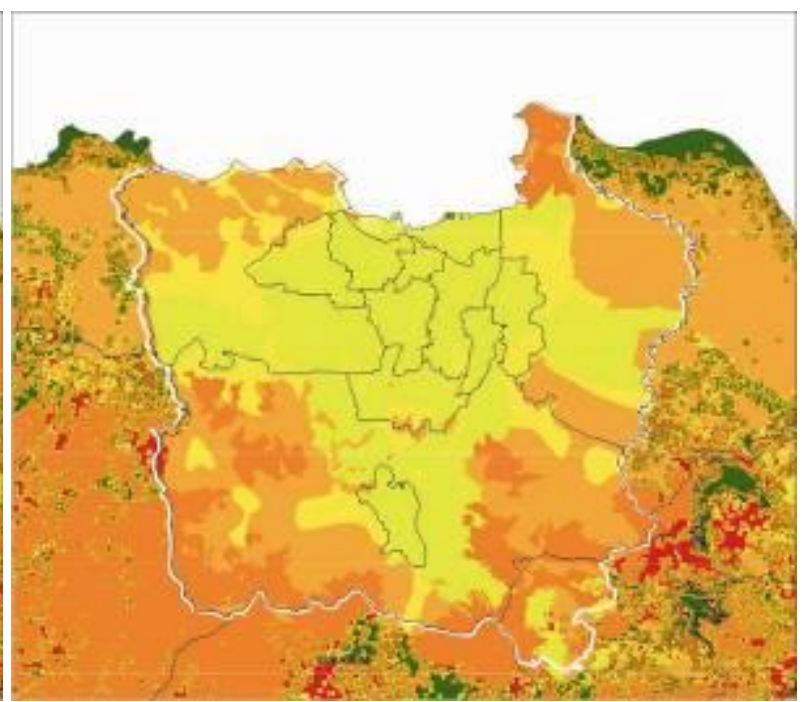

(b) Perpres 54/2008

Figure 18. Water holding capacity (WATERH) map for: (a) actual, and (b) Perpres 54/2008 scenarios

Figure 19 shows the hydrographs of computed river discharge for selected locations in the Ciliwung and Cisadane watersheds, under the two land cover scenarios. A full theoretical implementation of the Perpres 54/2008 scenario leads to a decrease in river discharge, with the largest decreases in the downstream area; the data are summarised in Table 7. The decreases in mean annual river discharge under the Perpres 54/2008 scenario are $0.1 \%, 0.8 \%$ and $2.2 \%$ (upper, middle, and downstream sections respectively of Citarum), and $4.4 \%, 4.7 \%$ and $5.6 \%$ (upper, middle, and downstream sections respectively of Cisadane). 


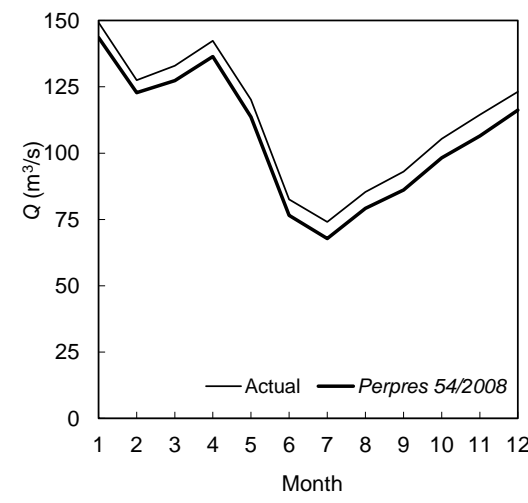

Downstream

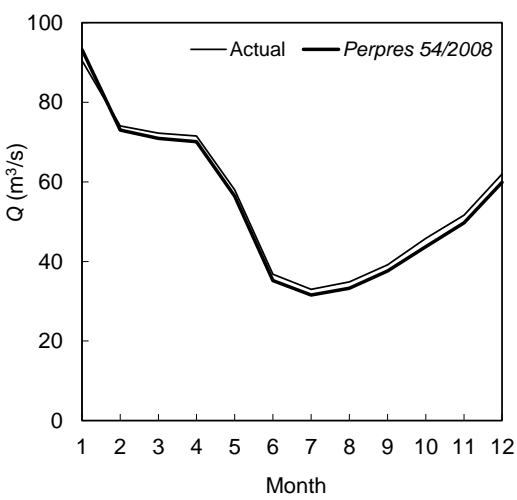

Downstream

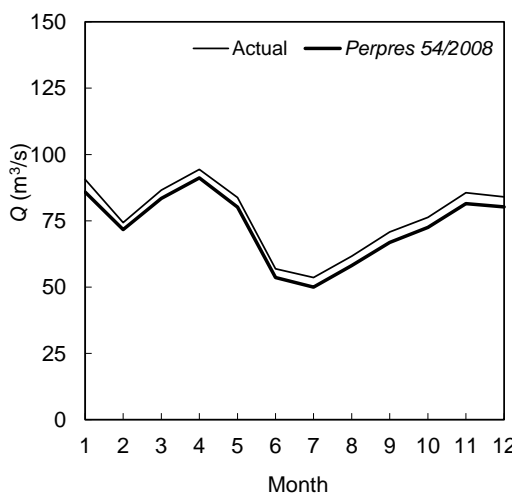

Middle

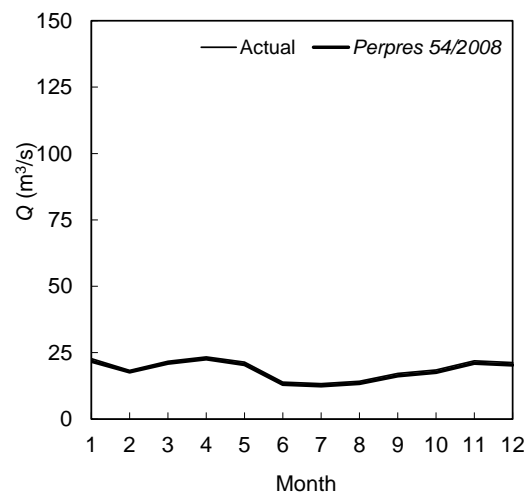

Upper

(a) Ciliwung

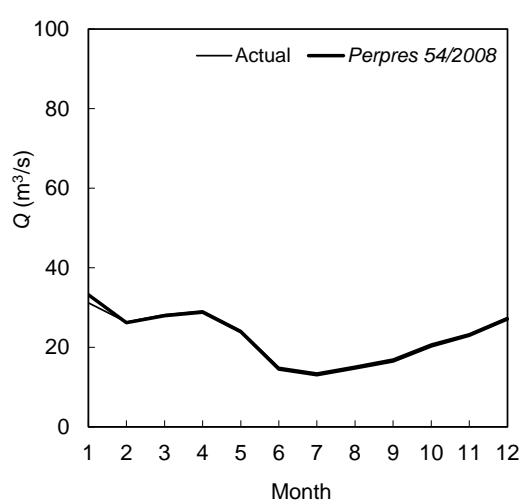

Middle

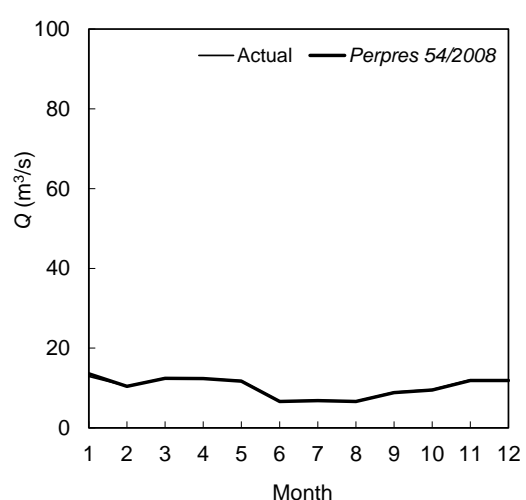

Upper

Figure 19. Computed mean monthly river discharge at selected evaluation points under the actual and Perpres 54/2008 scenarios in the (a) Ciliwung watershed and (b) Cisadane watershed.

Table 7. Computed monthly river discharge at selected locations under the actual and Perpres 54/2008 scenarios in the (a) Ciliwung watershed and (b) Cisadane watershed

\begin{tabular}{|c|c|c|c|c|c|c|}
\hline Watershed & Location & Scenario & Min & Max & Mean & $\Delta$ Mean $(\%)$ \\
\hline \multirow[t]{6}{*}{ Ciliwung } & \multicolumn{2}{|c|}{ Downstream Actual } & 33.0 & 90.5 & 55.8 & \multirow[t]{2}{*}{-2.2} \\
\hline & & Perpres & 31.6 & 93.3 & 54.6 & \\
\hline & \multirow[t]{2}{*}{ Middle } & Actual & 13.5 & 31.2 & 22.6 & \multirow[t]{2}{*}{-0.8} \\
\hline & & Perpres & 13.1 & 33.2 & 22.5 & \\
\hline & \multirow[t]{2}{*}{ Upper } & Actual & 6.7 & 12.9 & 10.2 & \multirow[t]{2}{*}{-0.1} \\
\hline & & Perpres & 6.6 & 13.6 & 10.2 & \\
\hline \multirow[t]{6}{*}{ Cisadane } & \multicolumn{2}{|c|}{ Downstream Actual } & 74.0 & 149.3 & 112.5 & \multirow[t]{2}{*}{-5.6} \\
\hline & & Perpres & 67.8 & 143.5 & 106.2 & \\
\hline & \multirow[t]{2}{*}{ Middle } & Actual & 53.6 & 94.4 & 76.5 & \multirow[t]{2}{*}{-4.7} \\
\hline & & Perpres & 50.0 & 91.2 & 72.9 & \\
\hline & \multirow[t]{2}{*}{ Upper } & Actual & 13.3 & 23.4 & 19.0 & \multirow[t]{2}{*}{-4.4} \\
\hline & & Perpres & 12.5 & 22.6 & 18.2 & \\
\hline
\end{tabular}

The decreases in river discharge are related to the increase in the water holding capacity of the soil (WATERH) and the increase in the so-called crop-factor (CROPF) due to land cover change. The changes in these factors are seen primarily in the buffer area of Jakarta, where the Cisadane watershed is located. Hence, Perpres 54/2008 causes a greater decrease in river discharge in the Cisadane watershed than in the Ciliwung. We used a similar approach to investigate the effectiveness of the theoretical implementation of the land cover plan in Perpres 54/2008 in reducing sediment yield. The so-called $C$-factor map in SDAS accounts for the erodibility of soil, which is based on known land cover. In Figure 20, we show maps of the $C$-factor under the actual and Perpres 54/2008 scenarios. It 
can be seen from Figure 20 that Perpres 54/2008 significantly increases the coverage of area with improved soil protection from erosion. Figure 21 shows the computed sediment yield under the actual and Perpres 54/2008 scenarios for the Ciliwung and Cisadane watersheds. From Figure 21, it can be seen that the theoretical implementation of Perpres 54/2008 could lead to large decreases in sediment yield: $61 \%$ for the Ciliwung, and $22 \%$ for the Cisadane (Table 8 ). The effects of a full implementation of Perpres 54/2008 on sediment yield are much greater than the effects on river discharge.

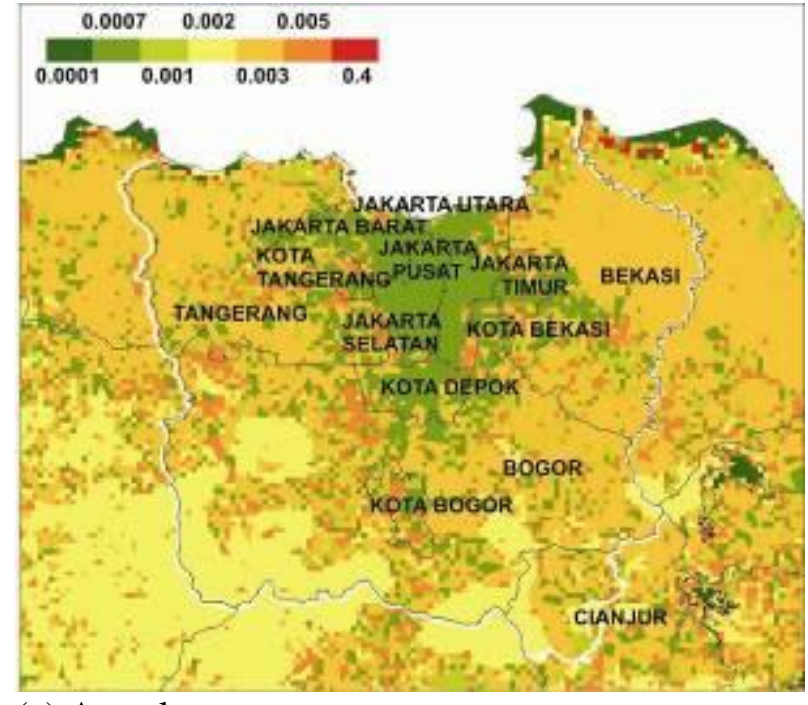

(a) Actual

Figure 20. $C$-factor map

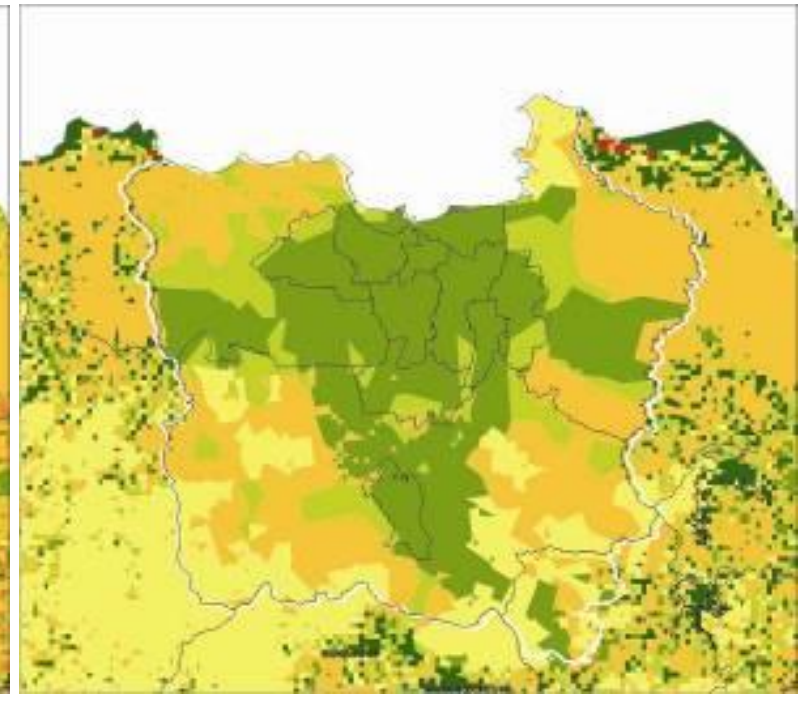

(b) Under Perpres 54/2008

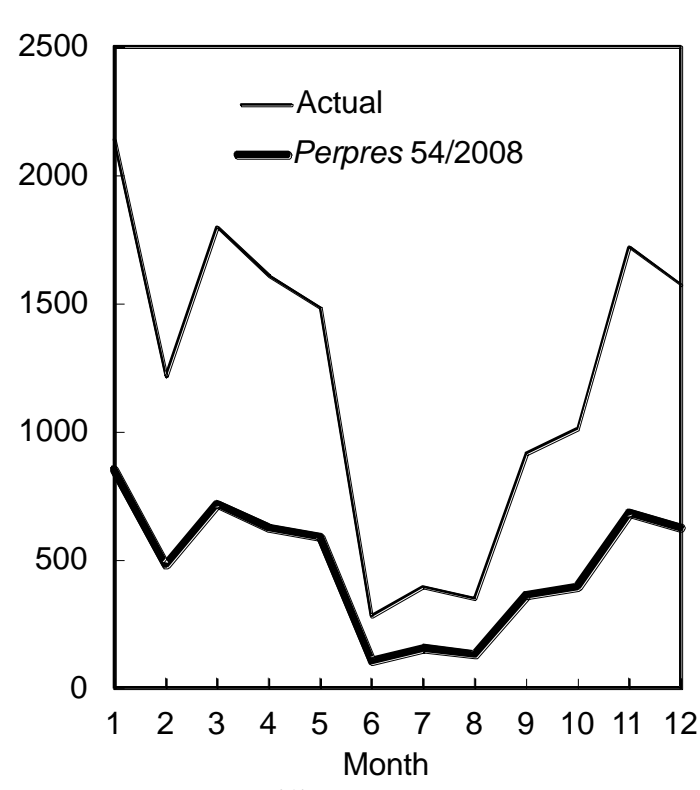

(a) Ciliwung

Figure 21. Computed mean monthly sediment yield ( $y$, in tons) in the Ciliwung and Cisadane watersheds under the actual and Perpres 54/2008 scenarios

Table 8. Computed annual sediment yield ( $y$, in tons) in the Ciliwung and Cisadane watersheds under the actual and Perpres 54/2008 scenarios

\begin{tabular}{lcrrrc}
\hline Watershed & Scenario & \multicolumn{1}{c}{ Min } & \multicolumn{1}{c}{ Max } & Mean & $\Delta$ Mean (\%) \\
\hline Ciliwung & Actual & 280 & 2137 & 1207 & -61 \\
& Perpres & 106 & 852 & 477 & \\
\hline Cisadane & Actual & 3,308 & 13,721 & 8,916 & -22 \\
& Perpres & 2,536 & 10,840 & 6,986 & \\
\hline
\end{tabular}


We computed the effects of a theoretical full implementation of the spatial plan described in Perpres $54 / 2008$ on both river discharge and sediment yield in the Cisadane and Ciliwung watersheds. The computed decreases in river discharge are $5.6 \%$ and $2.2 \%$ for the Cisadane and Ciliwung watersheds respectively. The computed decreases in sediment yield are $22 \%$ and $61 \%$ for the Cisadane and Ciliwung watersheds respectively. Hence, the results suggest that a full implementation of Perpres $54 / 2008$ could be beneficial to water and flood management in Jakarta, by both reducing the quantity of water entering the city, but more importantly by reducing the amount of sediment delivery to the city's waterways. It should be noted, however, that we did not specifically assess the impact of Perpres $54 / 2008$ on extreme discharges, i.e. peak daily river discharges.

In order to assess the significance of these decreases in river discharge and sediment yield, we compared the computed results for the Perpres 54/2008 and actual scenarios with theoretical best and worst case scenarios. For the river discharge simulation, the watersheds are assumed to have land covers of $100 \%$ forest and $100 \%$ built-up area, whereas for the sediment yield simulation, the watersheds are assumed to have $100 \%$ forest and $100 \%$ arable land. The results for river discharge are shown in Figure 22 and Table 9, and those for sediment yield are shown in Figure 23 and Table 10. Again, the results show that the scenarios have a greater potential for influencing sediment yield than influencing monthly discharge. Compared to the theoretical scenario of $100 \%$ built up area, discharge for the actual scenario is only 3.3\% and $2.5 \%$ lower in the Ciliwung and Cisadane watersheds respectively. In comparison, the sediment yield under the actual scenario is roughly $60 \%$ lower than under the 'worst case' scenario (i.e. fully arable land).

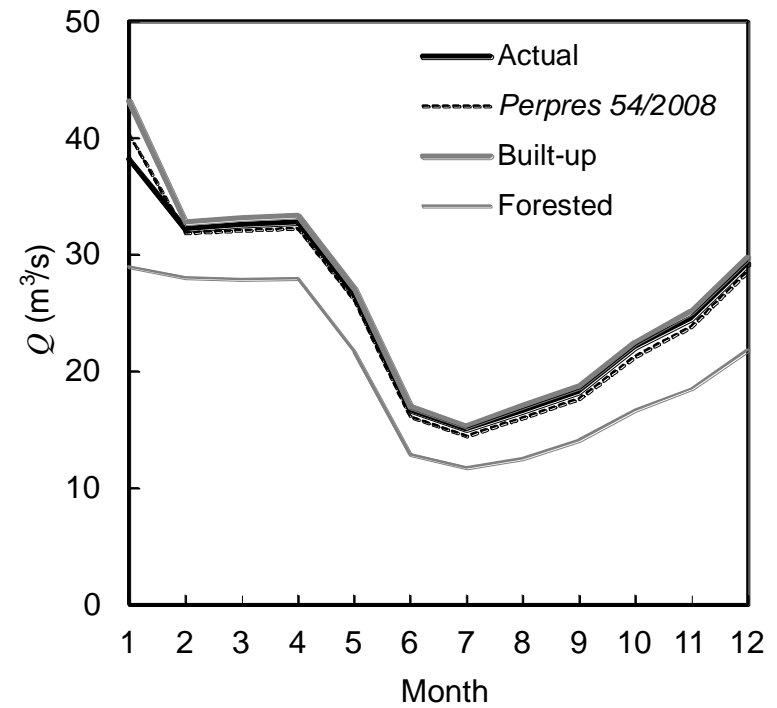

(a) Ciliwung

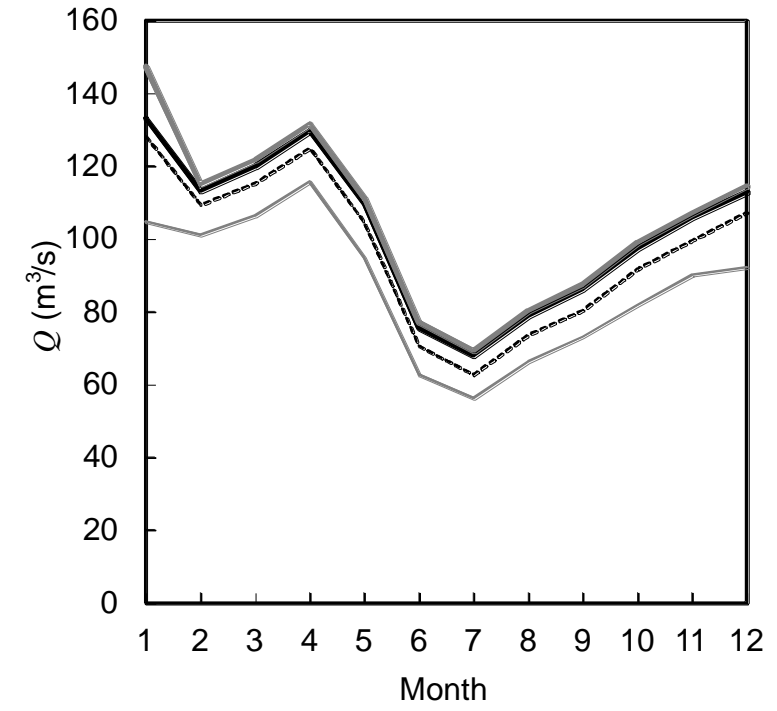

(b) Cisadane

Figure 22. Computed mean monthly river discharge $(Q)$ under the actual, Perpres 54/2008, 100\% built-up, and $100 \%$ forest scenarios in the Ciliwung and Cisadane watersheds

Table 9. Computed annual river discharge under the actual, Perpres 54/2008, 100\% built-up, and $100 \%$ forest scenarios in the Ciliwung and Cisadane watersheds

\begin{tabular}{llrrrr}
\hline Watershed & \multicolumn{1}{c}{ Scenario } & Min & Max & Mean & $\begin{array}{c}\Delta \text { to Actual } \\
\text { Scenario (\%) }\end{array}$ \\
\hline Ciliwung & Actual & 15.0 & 38.2 & 25.4 & \\
& Perpres 54/2008 & 14.5 & 40.3 & 25.0 & -1.4 \\
& Fully built-up & 15.3 & 43.2 & 26.2 & +3.3 \\
& Fully forested & 11.7 & 29.0 & 20.2 & -20.4 \\
\hline Cisadane & Actual & 68.0 & 133.0 & 102.5 & \\
& Perpres 54/2008 & 62.7 & 128.1 & 97.3 & -5.1 \\
& Fully built-up & 69.2 & 147.3 & 105.1 & +2.3 \\
& Fully forested & 56.1 & 115.6 & 87.0 & -15.1 \\
\hline
\end{tabular}




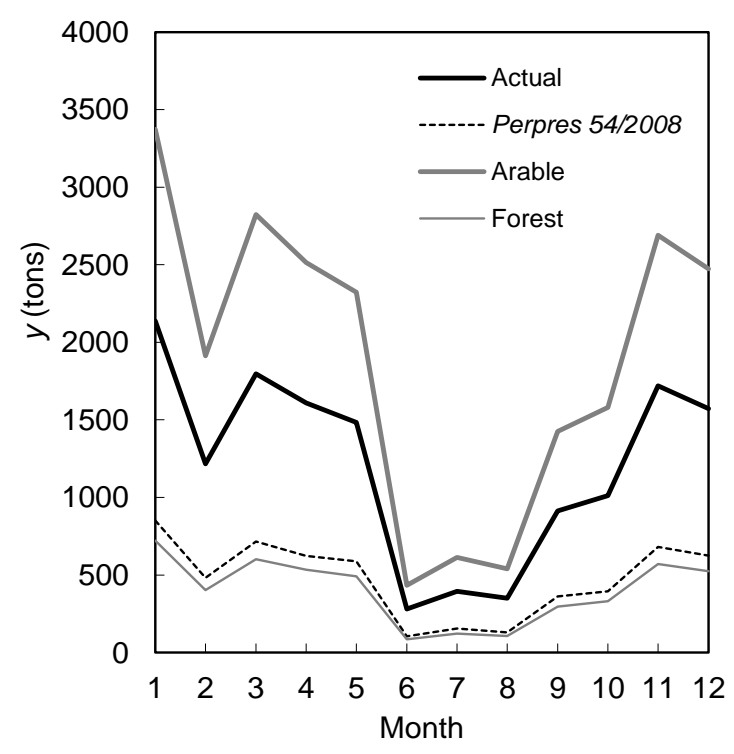

(a) Ciliwung

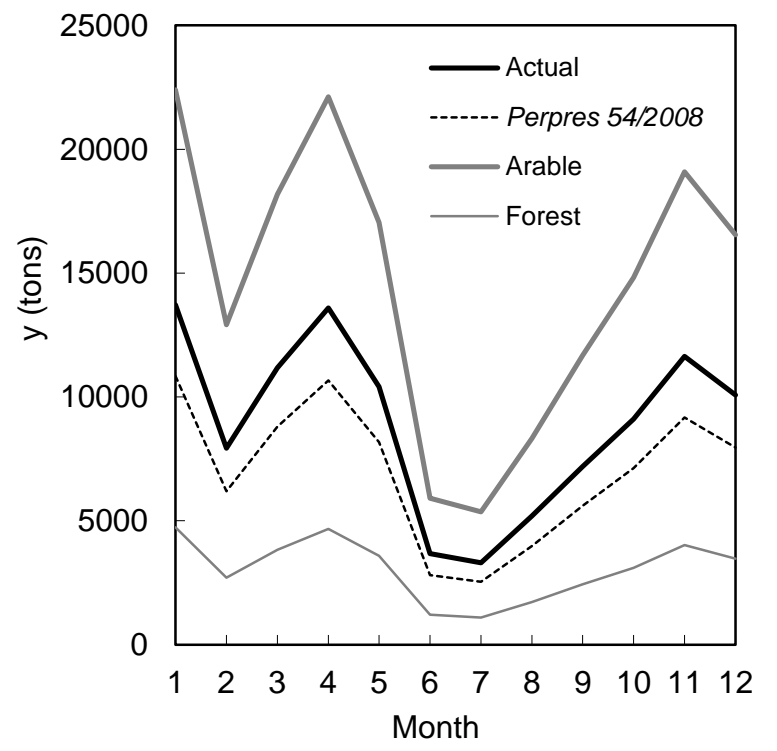

(b) Cisadane

Figure 23. Computed mean monthly sediment yield ( $y$, tons) under the actual, Perpres 54/2008, worst ( $100 \%$ arable land), and best (100\% forest) scenarios in the Ciliwung and Cisadane watersheds

Table 10. Computed annual sediment yield ( $y$, tons) under the actual, Perpres 54/2008, worst (100\% bareland), and best (100\% forest) scenarios in the Ciliwung and Cisadane watersheds

\begin{tabular}{llrrrc}
\hline Watershed & \multicolumn{1}{c}{ Scenario } & Min & Max & Mean & $\begin{array}{c}\Delta \text { to Actual } \\
\text { Scenario (\%) }\end{array}$ \\
\hline Ciliwung & Actual & 280 & 2,137 & 1,207 & \\
& Perpres 54/2008 & 106 & 852 & 477 & -61 \\
& Fully arable & 433 & 3,373 & 1,892 & +57 \\
& Fully forested & 85 & 721 & 399 & -67 \\
\hline Cisadane & Actual & 3,308 & 1,3721 & 8,916 & \\
& Perpres 54/2008 & 2,536 & 10,840 & 6,986 & -22 \\
& Fully arable & 5,359 & 22,396 & 14,529 & +63 \\
& Fully forested & 1,097 & 4,733 & 3048 & -66 \\
\hline
\end{tabular}

In Figures 24 and 25, we show how the river discharge and sediment yield under the actual and Perpres 54/2008 scenarios compare with theoretical best and worst case scenarios. For river discharge, the best case scenario is defined as a fully forested watershed and the worst case scenario is defined as a fully built-up watershed. For sediment yield, the best case scenario is defined as a fully forested watershed and the worst case scenario is defined as a arable land watershed. The figures show river discharge and sediment yield under the best case scenario as 100\%, and under the worst case scenario as $0 \%$. For Perpres 54/2008 and the actual scenario, the position relative to these extreme theoretical cases is shown. Figures 24 and 25 show the relative improvement in river discharge and sediment yield characteristics under the Perpres 54/2008 scenario as compared to the actual scenario. 


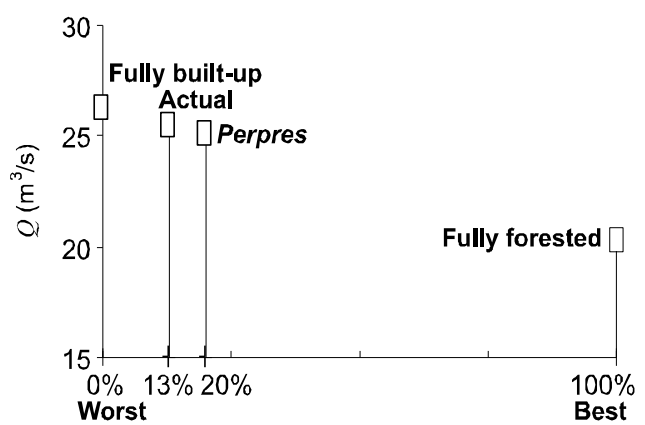

(a) Ciliwung

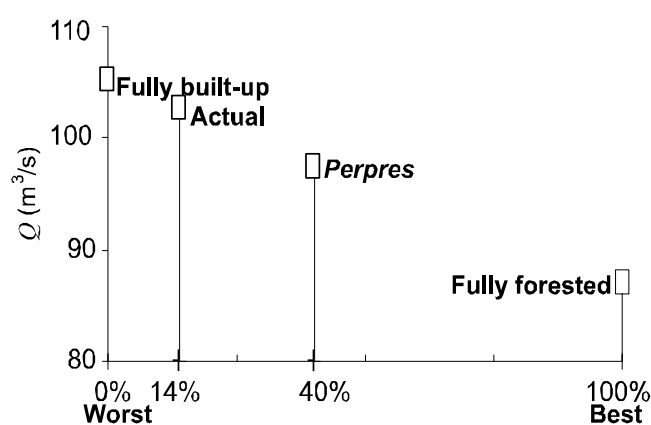

(b) Cisadane

Figure 24. River discharge $\left(\mathrm{m}^{3} / \mathrm{s}\right)$ under the actual and Perpres 54/2008 scenarios, relative to the worst case (fully built-up, $0 \%$ ) and best case (fully forested, 100\%) scenarios.

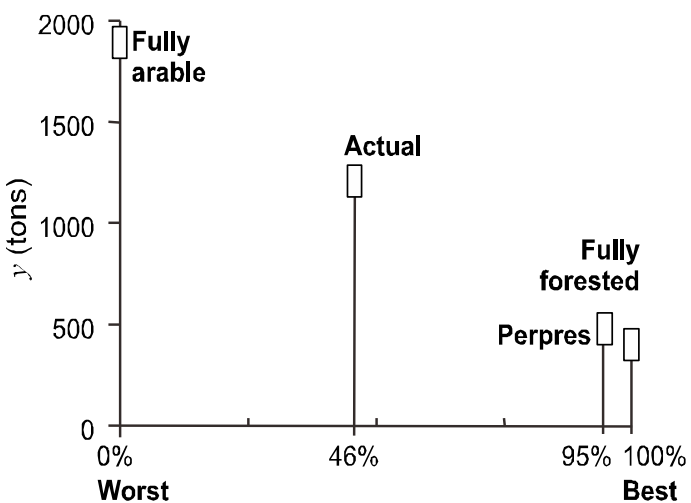

(a) Ciliwung

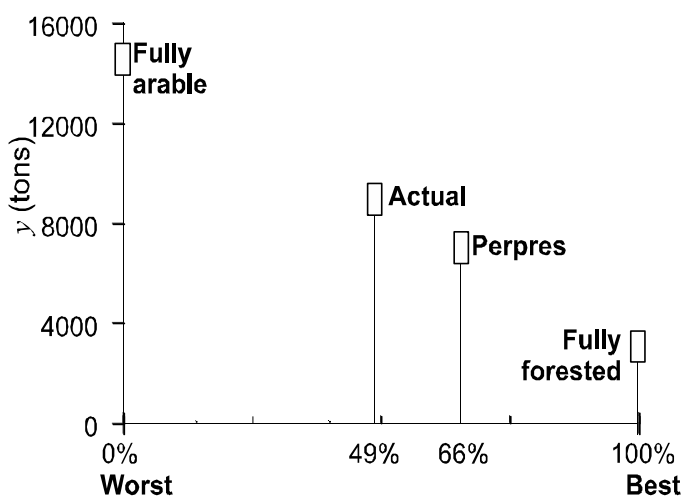

(b) Cisadane

Figure 25. Sediment yield (y, tons) under the actual and Perpres 54/2008 scenarios, relative to the worst case (fully arable, $0 \%$ ) and best case (fully forested, 100\%) scenarios.

\section{CONCLUSIONS}

In this study we applied the STREAM and SDAS models to assess the combined and individual impacts of changes in climate and land cover on river discharge and sediment yield for four watersheds in West Java, over the period 1901-2005. We also assessed how the river discharge and sediment yield could be affected by the theoretical full implementation of the spatial plan as described in Perpres 54/2008.

Over the course of the entire period 1901-2005, we found significant positive trends in sediment yield for all watersheds. The trends for river discharge were not statistically significant over this period. However, for the most recent period, we found significant positive trends in all watersheds for both sediment yield and discharge. The trends are stronger for sediment yield than for river discharge, suggesting that $20^{\text {th }}$ century changes in land cover and climate have had a larger impact on the former. This is corroborated by our investigation of the relative impacts of climate and land cover change: this shows that most of the computed increase in both sediment yield and discharge over the $20^{\text {th }}$ century was due to changes in land cover. Although we found that increased precipitation over the $20^{\text {th }}$ century would alone have led to increased discharge, this was largely compensated by increased temperature (and therefore increased evapotranspiration and reduced discharge). Spatial analyses of the sediment yield computations show that the area of land affected by medium to high erosion increased in all watersheds over the course of the study period, with the largest percentage areas of medium to high erosion in the Citarum watershed, especially in the upper watershed.

For both sediment yield and river discharge, we also identified cycles at periods of 1-, 4-, 6-, 10-, and 18-year periods; the cycles of medium periodicities may be related to ENSO, although further research would be required to confirm this. These cyclic periodicities are stronger for river discharge, especially for the higher frequency periodicities. This suggests that river discharge is more sensitive to inter-annual climate variability than is the case for sediment yield. 
We also computed the effects of a theoretical full implementation of the land cover plan described in Perpres 54/2008 on river discharge and sediment yield. According to the model results, a full implementation of this policy would lead to a modest decrease in mean annual river discharge of 5.6\% in the Cisadane and $2.2 \%$ in the Ciliwung watersheds. However, the results for sediment yield show reductions of $22 \%$ and $61 \%$ for the Cisadane and Ciliwung respectively. These findings are of potential significance for water and flood management in the city of Jakarta (and surroundings). Although relatively small, the implementation of Perpres 54/2008 could have a significant impact on discharge. It should, however, be noted that in this study we examined monthly discharge: for flood assessment the study should be extended to assess the effects of Perpres 54/2008 on (sub-)daily discharge. The results do suggest a large benefit for water and flood management due to reduced sediment yield. Sedimentation of the city's waterways (including the clogging of flood drainage networks) has greatly exacerbated the flood problem in recent years. Good spatial planning practices have the potential to reduce the amount of sediment delivered to the city, thus reducing to some extent the need for (and cost of) expensive dredging activities.

\section{ACKNOWLEDGEMENTS}

We thank the two anonymous reviewers for their comments on an earlier version of this manuscript. This research was funded by a SPIN grant (09-MP-10) from the Royal Netherlands Academy of Arts and Sciences (KNAW), and project HSINT02a of the Dutch research programme Knowledge for Climate and Delta Alliance. Philip J. Ward was also funded by a VENI grant from the Netherlands Organisation for Scientific Research (NWO).

\section{REFERENCES}

Abidin, H.Z., Andreas, H., Gumilar, I., Gamal, M., Susanti, P., Fukuda, Y. and Deguchi, T. (2010). Land subsidence in Jakarta Basin (Indonesia): characteristics, causes and impacts. IAHS book series Groundwater system response to a changing climate. Balkema: Lisse, The Netherlands, in press. Aerts, J., Droogers, P., 2004. Climate Change in Contrasting River Basins: Adaptation Strategies for Water, Food, and Environment. CABI Books, London.

Aerts, J.C.J.H., Kriek, M. and Schepel, M. (1999). STREAM, Spatial tools for river basins and environment and analysis of management options: Set up and requirements, Physics and Chemistry of the Earth Part B 24 (6), 591-595.

Aerts, J., Bouwer, L., Van Geel, G. and Ward, P.J. (2005). STREAM manual version 3.0. Institute for Environmental Studies (IVM), VU University Amsterdam.

Aerts, J.C.J.H., Renssen, H., Ward, P.J., De Moel, H., Odada, E., Bouwer, L.M. and Goosse, H. (2006). Sensitivity of Global River Discharges Under Holocene and Future Climate Conditions, Geophysical Research Letters, L19401.

Aldrian E. and Susanto, D. (2003). Identification of three dominant rainfall regions within Indonesia and their relationship to sea surface temperature, International Journal of Climatology 23:12, 1435-1452.

Aldrian, E., Dümenil Gates, L. and Widodo, F.H. (2007). Seasonal variability of Indonesian rainfall in ECHAM4 simulations and in the reanalyses: The role of ENSO. Theoretical and Applied Climatology 87:1-4, 41-59.

Amien, I., Rejekiningrum, P., Pramudia, A. and Susanti, E. (1996). Effects of interannual climate variability and climate change on rice yield in Java, Indonesia, Water, Air, and Soil Pollution 92, 29-39.

Bouwer, L.M, Aerts, J.C.J.H, van de Coterlet, G.M., van de Giesen, N, Gieske, A. and Mannaerts, C. (2004). Evaluating downscaling methods for preparing Global Circulation Model (GCM) data for hydrological impact modelling, In Aerts, J. and Droogers, P. (Eds.). Climate change in contrasting river basins: Adaptation strategies for water, food, and environment. CABI Publishing. Oxford, UK.

BPS Jakarta (2007). Jakarta dalam Angka 2007. Katalog BPS: 1403.31. Badan Pusat Statistik Propinsi DKI Jakarta, Jakarta, Indonesia.

Caljouw, M., Nas, P.J.M., and Pratiwo (2005). Flooding in Jakarta: Towards a blue city with improved water management. Bijdragen tot de Taal-, Land- en Volkenkunde (BKI) 161, 454-484. 
Duhamel, P. and Vetterli, M. (1990). Fast Fourier transforms: A tutorial review and a state of the art, Signal Processing 19, 259-299.

Firman, T. (2009). The continuity and change in mega-urbanization in Indonesia: A survey of JakartaBandung Region (JBR) development. Habitat International 33, 327-339. doi:10.1016/j.habitatint.2008.08.005.

Helsel, D.R. and Hirsch, R.M. (1992). Statistical Methods in Water Resources, Elsevier, Amsterdam.

Hendon, H.H. (2003). Indonesian Rainfall Variability: Impacts of ENSO and Local Air-Sea Interaction. Journal of Climate, 16, 1775-1790.

Julian, M.M., Nishio, F., Poerbandono and Ward, P.J. (2011). Simulation of river discharges in major watersheds of northwestern Java from 1901 to 2006, International Journal of Technology 2(1), 10-19.

Kartikasari, R. (2009). Analisis kuadrat terkecil untuk penentuan trend linier perubahan kedudukan muka laut berdasarkan data satelit altimetri TOPEX (1992-2002) dan JASON-1 (2002-2009) (Studi Kasus: Wilayah Perairan Indonesia), Tugas Akhir, Program Studi Teknik Geodesi dan Geomatika, Institut Teknologi Bandung.

Lu, H., Moran, C.J. and Prosser, I.P. (2003). Modelling Sediment Delivery Ratio over the Murray Darling Basin, CSIRO Land and Water, Elsevier Ltd., Canberra, Australia.

Mitchell, T.D., Carter, T.R., Jones, P.D., Hulme,M. and New, M. (2004). A comprehensive set of high-resolution grids of monthly climate for Europe and the globe: the observed record (19012000) and 16 scenarios (2001-2100). Tyndall Centre for Climate Change Research Working Paper, 55, 25..

New, M., Lister, D., Hulme, M. and Makin, I. (2002). A high-resolution dataset of surface climate over global land areas, Climate Research 21, 1-25.

Poerbandono, Basyar, A. and Harto, A.B. (2006). Spatial modelling of sediment transport over the upper Citarum catchment, ITB Journal on Engineering Science 38 (1), 11-28.

Poerbandono, Harto, A.B. and Julian, M.M (in review). Spatial Decision Assistance of Watershed Sedimentation (SDAS): Development and application. Submitted to ITB Journal on Engineering Science.

Poerbandono, Ward, P.J. and Julian, M.M. (2009). Set up and calibration of a spatial tool for simulating river discharge of western Java in recent decades: Preliminary results and assessments, ITB Journal on Engineering Science 41 (1), 50-64.

Qian, J.-H., Robertson, A.W. and Moron, V. (2010). Interactions among ENSO, the monsoon, and diurnal cycle in rainfall variability over Java, Indonesia. Journal of the Atmospheric Sciences 67:11, 3509-3524.

San, C.L., Raghavan, S.V., Shie, Y.L., and Sanders, R. (2012). Development of intensity duration frequency Curve S: Incorporating climate change projection. Proceedings of the 10th International Conference on Hydroinformatics, Hamburg, Germany.

Scalenghe, R. and Marsan, F.A. (2009).The anthropogenic sealing of soils in urban areas. Landscape and Urban Planning 90, 1-10.

Sivapalan, M., Jothityankuun, C. and Menabde, M. (2002). Linearity and non-linearity of basin response as a function of scale: Discussion of alternative definitions, Water Resources Research 38 (2), 4.1-4.5.

Steinberg, F. (2007). Jakarta: Environmental problems and sustainability. Habitat International 31, 354-365.

Texier, P. (2008). Floods in Jakarta: When the extreme reveals daily structural constraints and mismanagement. Disaster Management and Prevention 17, 358-372.

Thornthwaite, C.W. (1948). An approach toward a rational classification of climate, Geographical Review 38, 55-94.

Thornthwaite, C.W. and Mather, J.R. (1957). Instructions and tables for computing potential evapotranspiration and the water balance, Publications in Climatology 10 (3), 183-243.

Verburg, P.H., Veldkamp, T.A., Bouma, J. (1999). Land use change under conditions of high population pressure: The case of Java. Global Environmental Change 9, 303-312, doi:10.1016/S0959-3780(99)00175-2. 
Ward, P.J., Aerts, J.C.J.H., de Moel, H. and Renssen, H. (2007). Verification of a coupled climatehydrological model against holocene palaeohydrological records, Global and Planetary Change 57, 283-300.

Ward, P.J., Beets, W., Bouwer, L.M., Aerts, J.C.J.H. and Renssen, H. (2010). Sensitivity of river discharge to ENSO. Geophysical Research Letters 37, L12402, doi:10.1029/2010GL043215.

Ward, P.J., Marfai, M.A., Yulianto, F., Hizbaron, D.R. and Aerts, J.C.J.H. (2011a). Coastal inundation and damage exposure estimation: A case study for Jakarta. Natural Hazards 56 (3), 899-916, doi:10.1007/s11069-010-9599-1.

Ward, P.J., Pauw, W.P., Van Buuren, M.W. and Marfai, M.A. (2013). Governance of flood risk management in a time of climate change: The cases of Jakarta and Rotterdam. Environmental Politics, 22(3), 518-536, doi:10.1080/09644016.2012.683155.

Ward, P.J., Renssen, H., Aerts, J.C.J.H. and Verburg, P.H. (2011b). Sensitivity of discharge and flood frequency to 21st century and late Holocene changes in climate and land use (River Meuse, northwest Europe). Climatic Change 106 (2), 179-202, doi:10.1007/s10584-010-9926-2.

Ward, P.J., Renssen, H., Aerts, J.C.J.H., van Balen, R.T. and Vandenberghe, J. (2008). Strong increases in flood frequency and discharge of the River Meuse over the late Holocene: Impacts of long-term anthropogenic land use change and climate variability, Hydrology and Earth System Sciences 12, 159-175.

Ward, P.J., Eisner, S., Flörke, M., Dettinger, M.D., and Kummu, M. (2014). Annual flood sensitivities to El Niño Southern Oscillation at the global scale. Hydrology and Earth System Sciences 18, 4766, doi: 10.5194/hess-18-47-2014

Wei, Y., Santhana-Vannan, S.-K., and Cook, R.B. (2009). Discover, visualize, and deliver geospatial data through OGC standards-based WebGIS system, Proceedings of the 17th International Conference on Geoinformatics, pp.1-6, 12-14 Aug. 2009.

Whitten, T., Soeriaatmadja, R.E. and Afiff, S.A. (1996). The ecology of Java and Bali, Periplus Editions.

Wischmeier, W.H. and Smith, D.D. (1978). Predicting rainfall erosion losses - A guide to conservation planning, US Department Agricultural Handbook No. 537. 


\author{
AUTHORS \\ ${ }^{1}$ Poerbandono \\ poerbandono@gd.itb.ac.id \\ Faculty of Earth Sciences and Technology \\ Institute of Technology, Bandung - Indonesia \\ Jalan Ganesha 10 \\ Bandung 40132 \\ Indonesia \\ Tel.: +62(0)22 2530701 \\ Fax.: +62(0)22 2530702 \\ ${ }^{2}$ Miga M. Julian \\ miga-magenika.julian@uni-jena.de \\ Institut für Geographie \\ Lehrstuhl für Geoinformatik, Geohydrologie und Modellierung \\ Friedrich-Schiller-Universität, Jena - Germany \\ Löbdergraben 32 \\ 07743 Jena \\ Germany \\ Tel.: +49 (0) 3641948877 \\ Fax: +49 (0) 3641948852 \\ ${ }^{3}$ Philip J. Ward \\ philip.ward@ivm.vu.nl \\ Institute for Environmental Studies (IVM) \\ VU University, Amsterdam - the Netherlands \\ De Boelelaan 1087 \\ 1081 HV Amsterdam \\ The Netherlands \\ Tel.: +31205986149 \\ Fax.: +31-20-5989 553
}

